\title{
Probiotic Potential of Lactobacillus Strains with Antimicrobial Activity against Some Human Pathogenic Strains
}

\author{
Parisa Shokryazdan, ${ }^{1}$ Chin Chin Sieo, ${ }^{1,2}$ Ramasamy Kalavathy, ${ }^{3}$ Juan Boo Liang, \\ Noorjahan Banu Alitheen, ${ }^{2}$ Mohammad Faseleh Jahromi, ${ }^{4}$ and Yin Wan Ho ${ }^{1}$ \\ ${ }^{1}$ Institute of Bioscience, Universiti Putra Malaysia (UPM), 43400 Serdang, Selangor, Malaysia \\ ${ }^{2}$ Faculty of Biotechnology and Biomolecular Sciences, Universiti Putra Malaysia (UPM), 43400 Serdang, Selangor, Malaysia \\ ${ }^{3}$ Faculty of Pharmacy, Universiti Teknologi MARA, 42300 Puncak Alam, Selangor, Malaysia \\ ${ }^{4}$ Institute of Tropical Agriculture, Universiti Putra Malaysia (UPM), 43400 Serdang, Selangor, Malaysia
}

Correspondence should be addressed to Yin Wan Ho; ywho@upm.edu.my

Received 12 April 2014; Revised 10 June 2014; Accepted 10 June 2014; Published 3 July 2014

Academic Editor: Frederick D. Quinn

Copyright (C) 2014 Parisa Shokryazdan et al. This is an open access article distributed under the Creative Commons Attribution License, which permits unrestricted use, distribution, and reproduction in any medium, provided the original work is properly cited.

\begin{abstract}
The objective of this study was to isolate, identify, and characterize some lactic acid bacterial strains from human milk, infant feces, and fermented grapes and dates, as potential probiotics with antimicrobial activity against some human pathogenic strains. One hundred and forty bacterial strains were isolated and, after initial identification and a preliminary screening for acid and bile tolerance, nine of the best isolates were selected and further identified using $16 \mathrm{~S}$ rRNA gene sequences. The nine selected isolates were then characterized in vitro for their probiotic characteristics and their antimicrobial activities against some human pathogens. Results showed that all nine isolates belonged to the genus Lactobacillus. They were able to tolerate pH 3 for $3 \mathrm{~h}, 0.3 \%$ bile salts for $4 \mathrm{~h}$, and $1.9 \mathrm{mg} / \mathrm{mL}$ pancreatic enzymes for $3 \mathrm{~h}$. They exhibited good ability to attach to intestinal epithelial cells and were not resistant to the tested antibiotics. They also showed good antimicrobial activities against the tested pathogenic strains of humans, and most of them exhibited stronger antimicrobial activity than the reference strain L. casei Shirota. Thus, the nine Lactobacillus strains could be considered as potential antimicrobial probiotic strains against human pathogens and should be further studied for their human health benefits.
\end{abstract}

\section{Introduction}

Probiotics are defined as "live microorganisms which when administered in adequate amounts confer a health benefit on the host" [1]. During the last decade, the use of probiotics for human has received increasing attention as scientific evidence continues to accumulate on the properties, functionality, and beneficial effects of probiotic bacteria on humans. The search for more new probiotics is driven by the growing demand for probiotic functional food and beverages and dietary supplements due to rising levels of health consciousness and growing consumer awareness regarding gut health and the concept of preventive health care. It is now well established that some of the infections and disorders in the human body, such as irritable bowel syndrome, inflammatory bowel disease, and antibiotic-induced diarrhea, could be due to deficient or compromised intestinal microflora, and probiotics have been considered to be one of the disease control strategies to overcome such disorders [2]. Thus, probiotics have become increasingly considered for use in the food industry. Lactic acid bacteria, especially Lactobacillus, are the most commonly used microorganisms as probiotics because of the perception that they are desirable members of the intestinal microflora and because these bacteria have "Generally Recognized As Safe" (GRAS) status. The growing interest in probiotics has resulted in many purported probiotic products being marketed without adequate studies on the probiotic properties of the strains leading to problems of inconsistent efficacy of the products. Since the properties of probiotic are strain-specific, the quality of products is closely linked to the individual strains in the products. Thus, they should be correctly identified, and their probiotic 
properties properly studied. However, several studies have reported misidentification or mislabeling of probiotic species or presence of unspecified species in many commercial probiotic products [3-7]. The guidelines proposed by FAO/WHO [8] for evaluation of probiotics recommended that every potential probiotic strain should be correctly identified using both phenotypic and genotypic methods, followed by various tests to investigate its survival ability and functional properties. Acidity, presence of bile salts, and pancreatic enzymes in the gastrointestinal tract (GIT) are some of the major stresses that an orally taken probiotic encountered in the GIT. It is essential that a potential probiotic strain is able to tolerate these stress conditions in order to survive in the GIT. Apart from being able to survive, a probiotic strain also has to be able to adhere to and subsequently colonize (at least temporarily) the intestinal tract. Since the GIT is a dynamic environment, the flow of the gut digesta may wash out any bacterium not attached to the intestinal mucosa. Thus, probiotic strains with adherent ability are more likely to have an increased opportunity to colonize the GIT. The transmission of antibiotic resistance genes from food bacteria to commensal or pathogenic bacteria in the gut is a major health concern. In recognition of the importance of assuring safety, the FAO/WHO [8] guidelines recommended that the antibiotic resistance/susceptibility pattern of every probiotic strain (including bacteria with GRAS status) be determined.

Recent concerns on the rampant and indiscriminate use of antibiotics for disease treatments and growth promotion of livestock and the development of antibiotic resistant pathogens have led to increased interest in the application of probiotics and their antimicrobial metabolites as alternative antimicrobial strategies for treatment and prevention of infections. Hence, antimicrobial activity against pathogens is a desirable property of a potential probiotic strain.

The present study was carried out to isolate, identify, and characterize some lactic acid bacteria from human milk, infant feces, and fermented grapes and dates, as potential probiotics with antimicrobial activity against microorganisms that are pathogenic to humans. The probiotic properties were investigated through in vitro assays.

\section{Materials and Methods}

2.1. Isolation of Lactic Acid Bacteria. Samples of breast milk were collected aseptically from five healthy women, within four months of given birth to healthy babies, in Kuala Lumpur, Malaysia. The nipple and mammary areola of the breast were wiped with $70 \%$ ethanol and about $5 \mathrm{~mL}$ of milk was collected in a sterile test tube using a sterile breast pump. Samples of infant feces were collected in sterile test tubes from five healthy breast-fed infants of one to four months old, in Kuala Lumpur, Malaysia. Informed consents were obtained from the donors of breast milk and mothers of the infants. Samples of fermented grapes and dates were obtained from Iranian fermented grapes and dates which are commonly used as condiments to flavor or complement foods. The grapes and dates ( $500 \mathrm{~g}$ each) were fermented in $100 \mathrm{~mL}$ of water and $20 \mathrm{~g} \mathrm{NaCl}$ in $1 \mathrm{~L}$ bottles for 40 days at room temperature. Samples were taken from five bottles of fermented grapes and five bottles of fermented dates. Each bottle was shaken by hand for $30 \mathrm{~s}$ and left to stand for $5 \mathrm{~min}$ at room temperature, after which the supernatant was collected.

Tenfold serial dilutions of $10^{-8}$ to $10^{-10}$ of the samples were prepared using $0.5 \%$ peptone water (Sigma, USA). From each dilution, $100 \mu \mathrm{L}$ was spread-plated on de Man, Rogosa and Sharpe (MRS) agar medium (Merck, Germany) and incubated for $72 \mathrm{~h}$ at $37^{\circ} \mathrm{C}$ in anaerobic jars (Oxoid, UK) containing gaspack (AnaeroGen, Oxoid, UK) (oxygen level $<1 \%, \mathrm{CO}_{2}$ level between 9 and 13\%). After the incubation period, colonies were randomly picked from the plates and subcultured three times on fresh MRS agar plates. The cultures were kept in MRS broth containing 20\% (v/v) glycerol at $-80^{\circ} \mathrm{C}$.

One hundred and forty bacterial strains were isolated from human milk, infant feces, fermented dates, and fermented grapes. Of the 140 isolates, 42 were from fermented dates, 30 from fermented grapes, 32 from breast milk, and 36 from infant feces. Gram staining and catalase test on the isolates showed that, out of 140 isolates, 94 isolates were gram positive and catalase negative, indicating that they were probably lactic acid bacteria (LAB). A rapid preliminary screening for acid and bile tolerance using turbidity (OD at $620 \mathrm{~nm}$ ) as a growth measurement was then carried out on these isolates. For acid tolerance, $1 \%(\mathrm{v} / \mathrm{v})$ of overnight culture ( 7 to $8 \log \mathrm{CFU} / \mathrm{mL}$ ) was inoculated into phosphate buffer saline (PBS) $\left(8 \mathrm{~g} \mathrm{NaCl}, 0.2 \mathrm{~g} \mathrm{KCl}, 1.44 \mathrm{~g} \mathrm{Na} \mathrm{HPO}_{4}\right.$, and $0.24 \mathrm{~g} \mathrm{KH}_{2} \mathrm{PO}_{4}$ in $1 \mathrm{~L}$ distilled water) at $\mathrm{pH} 7.2$ (control) and $\mathrm{pH} 3$ (adjusted with $1 \mathrm{~N} \mathrm{HCL}$ ) (acidic condition). The culture was then incubated at $37^{\circ} \mathrm{C}$ for $3 \mathrm{~h}$, after which $1 \%(\mathrm{v} / \mathrm{v})$ of cell suspension was inoculated into $10 \mathrm{~mL}$ of MRS broth and incubated at $37^{\circ} \mathrm{C}$ for $24 \mathrm{~h}$. Cell growth was assessed by measuring optical density (OD) at $620 \mathrm{~nm}$. For the bile tolerance, $1 \%(\mathrm{v} / \mathrm{v})$ of overnight culture (7 to $8 \mathrm{log}$ $\mathrm{CFU} / \mathrm{mL}$ ) was inoculated into $10 \mathrm{~mL}$ of MRS broth with or without (control) $0.3 \%(\mathrm{w} / \mathrm{v})$ oxgall (Sigma, USA) and incubated at $37^{\circ} \mathrm{C}$ for $4 \mathrm{~h}$, after which growth was assessed by measuring $\mathrm{OD}$ at $620 \mathrm{~nm}$. From this preliminary screening, three isolates from human milk, three isolates from infant feces, one isolate from fermented grapes, and two isolates from fermented dates, which exhibited growth of over $80 \%$ at $\mathrm{pH} 3$ and $0.3 \%$ oxgall (in comparison to control), were selected for identification and in vitro assays for probiotic properties. In the in vitro assays, a commercial probiotic Lactobacillus strain, L. casei Shirota, from Yakult fermented milk, was used as a reference strain. Lactobacillus casei Shirota was obtained from the culture collection of the Faculty of Pharmacy, Universiti Teknologi MARA, Malaysia.

2.2. Identification. Overnight culture $(1.5 \mathrm{~mL})$ of each of the nine $\mathrm{LAB}$ isolates in MRS broth was centrifuged at $5000 \times \mathrm{g}$ for $10 \mathrm{~min}$ at room temperature. The cell pellet was used for extraction of total genomic DNA using the DNeasy Blood and Tissue Kit (Qiagen, Germany). For amplification of the 16S rRNA gene, universal primers F27 (5'-AGAGTTTGAT CMTGGCTCAG-3') and R1492 $\left(5^{\prime}\right.$-TACGGYTACCTTGTTACGACTT- $\left.{ }^{\prime}\right)$ were used $[9,10]$ 
with expected PCR product size of $1.5 \mathrm{~kb}$. The PCR amplification was performed in $25 \mu \mathrm{L}$ reaction mixtures using a MyCycler Thermal Cycler (BioRad, USA). The PCR reaction mixture contained $2.5 \mu \mathrm{L}$ of PCR buffer (10X PCR amplification buffer containing $500 \mathrm{mM} \mathrm{KCl}, 100 \mathrm{mM}$ Tris- $\mathrm{HCl}$ (pH 9.0), and $1 \%$ Triton X-100), $0.5 \mu \mathrm{L}$ of deoxynucleotide triphosphate (dNTP, i-DNA Biotechnology, Singapore) in concentration of $10 \mathrm{mM}, 0.5 \mu \mathrm{L}$ of each primer in concentration of $10 \mu \mathrm{M}, 20 \mu \mathrm{L}$ of deionised water, $0.5 \mu \mathrm{L}$ of Taq DNA polymerase (Viogene, Taiwan, $2 \mathrm{U} / \mu \mathrm{L}$ ), and $0.5 \mu \mathrm{L}$ of template DNA (corresponding to approximately 50 to $100 \mathrm{ng}$ of DNA). The PCR conditions were as follows: initial denaturation at $94^{\circ} \mathrm{C}$ for $4 \mathrm{~min}, 30$ cycles of denaturation at $94^{\circ} \mathrm{C}$ for $1 \mathrm{~min}$ each, primer annealing at $55^{\circ} \mathrm{C}$ for $30 \mathrm{~s}$ and primer extension at $72^{\circ} \mathrm{C}$ for $2 \mathrm{~min}$, and a final step of primer extension at $72^{\circ} \mathrm{C}$ for $5 \mathrm{~min}$. The PCR product with expected size of $1.5 \mathrm{~kb}$ was excised from the gel and purified using MEGAquick-spin PCR and Agarose Gel DNA Extraction System (iNtRON Biotechnology, Korea). Each purified PCR product was ligated into PCR 2.1 TOPO vector using a TOPO TA cloning kit (Invitrogen, USA) and cloned into E. coli TOP 10 according to the manufacturer's instructions. The DNA sequence analysis was carried out for plasmid with the unique insert using an ABI 373XL automated sequencer (Applied Biosystems, USA) at both directions to obtain the full sequence of the amplicons. DNA sequence data sets were assembled using the Bioedit sequence alignment editor software, version 7.0.9.0 [11]. Sequence similarity values were determined using the basic local alignment search tool (BLAST) of the National Centre of Biotechnology Information (NCBI) [12]. Sequences with $\geq 97 \%$ similarity to the previously published sequences were used as the criteria to indicate species identity. Sequence alignment was carried out using CLUSTAL W program of the Bioedit software version 7. A phylogenetic tree was constructed based on the $16 \mathrm{~S}$ rRNA gene sequence analysis where the analysis involved 51 nucleotide sequences comprising nine sequences of LAB obtained in this study, 41 sequences belonging to Lactobacillus species that were obtained from the GenBank and the sequence of Lactococcus lactis (AB100803.1) which was used as an outgroup. Evolutionary analyses were conducted using molecular evolutionary genetic analyses (MEGA) version 5. The evolutionary history was inferred using the neighborjoining method. Bootstrapping was performed for 1000 replicates and the evolutionary distances were computed using the Tamura 3-parameter method [13]. Potential anomalous sequences of the $16 \mathrm{~S}$ rRNA gene were examined by the Mallard [14] and the Bellerophon [15] programs. Nucleotide sequences of nine LAB isolates determined in this study were deposited in the GenBank (NCBI) database.

\subsection{In Vitro Assessment of Characteristics for Survival in the Gastrointestinal Tract}

2.3.1. Acid Tolerance. The acid tolerance assay was tested according to Ehrmann et al. [16] with modifications. Cells of each LAB strain (in a final concentration of 7 to $8 \log$ $\mathrm{CFU} / \mathrm{mL} \mathrm{PBS})$ were inoculated $(1 \%, \mathrm{v} / \mathrm{v})$ into sterile $\mathrm{PBS}$, adjusted to $\mathrm{pH} 3$ with $1 \mathrm{~N} \mathrm{HCl}$ (acidic condition) and PBS with normal pH 7.2 (control), and incubated anaerobically for $3 \mathrm{~h}$ at $37^{\circ} \mathrm{C}$. After incubation, tenfold serial dilutions (up to $10^{-7}$ ) of each bacterial strain were prepared using PBS. Then $100 \mu \mathrm{L}$ of $10^{-4}$ to $10^{-7}$ dilutions from each sample was spreadplated on MRS agar and incubated anaerobically at $37^{\circ} \mathrm{C}$ for $24 \mathrm{~h}$. After incubation, colonies on the plates were counted and enumerated as CFU/mL. Tolerance to acidic condition was estimated by comparing viable cell counts after exposure to acidic ( $\mathrm{pH} 3$ ) and normal (control) conditions. The assay was performed twice, each in triplicate.

2.3.2. Bile Tolerance. The bile tolerance assay was tested according to Jacobsen et al. [17] with modifications. Overnight culture of each LAB strain, adjusted to a final concentration of 7 to $8 \log \mathrm{CFU} / \mathrm{mL}$, was inoculated $(1 \%$, $\mathrm{v} / \mathrm{v}$ ) into $10 \mathrm{~mL}$ of fresh MRS broth with or without (control) $0.3 \%(\mathrm{w} / \mathrm{v})$ oxgall and incubated anaerobically at $37^{\circ} \mathrm{C}$ for $4 \mathrm{~h}$, after which tenfold serial dilutions of up to $10^{-7}$ were prepared using PBS. Then $100 \mu \mathrm{L}$ of $10^{-4}$ to $10^{-7}$ dilutions from each sample was spread-plated on MRS agar and incubated anaerobically at $37^{\circ} \mathrm{C}$ for $24 \mathrm{~h}$. After incubation, viability of bacterial cells was assessed by colony counts $(\mathrm{CFU} / \mathrm{mL})$ on the plates. Bile tolerance was estimated by comparing viable cell counts in MRS with and without bile (oxgall).

2.3.3. Pancreatic Enzyme Tolerance. Tolerance to pancreatic enzymes was tested according to the method of Rönkä et al. [18] with modifications. Harvested cell pellet of overnight culture of each LAB strain was resuspended in PBS to a final concentration of 7 to $8 \log \mathrm{CFU} / \mathrm{mL}$ and $1 \%(\mathrm{v} / \mathrm{v})$ of resuspended cells was inoculated into $10 \mathrm{~mL}$ of the test solution (PBS containing $150 \mathrm{mM} \mathrm{NaHCO}{ }_{3}$ and $1.9 \mathrm{mg} / \mathrm{mL}$ pancreatin (Sigma, USA), $\mathrm{pH}$ 8) and control solution (PBS, $\mathrm{pH}$ 7.2). The cultures were incubated anaerobically at $37^{\circ} \mathrm{C}$ for $3 \mathrm{~h}$. After incubation, tenfold serial dilutions of up to $10^{-7}$ were prepared using PBS and $100 \mu \mathrm{L}$ of $10^{-4}$ to $10^{-7}$ dilutions from each sample was spread-plated on MRS agar. The plates were incubated anaerobically at $37^{\circ} \mathrm{C}$ for $24 \mathrm{~h}$, after which viability of bacterial cells was assessed by colony counts $(\mathrm{CFU} / \mathrm{mL})$. Tolerance to pancreatic enzymes was estimated by comparing viable cell counts in test solution and control solution.

2.3.4. Adherence Assay. The human intestinal epithelial cell line, Caco-2 cell line (ATCC 2102-CRL), was used in the adherence assay. The Caco- 2 cells were routinely grown to 80-85\% confluent in Dulbecco's Modified Eagle Medium (DMEM) (Sigma, USA) supplemented with $20 \%$ (v/v) fetal bovine serum (FBS) (Sigma, USA), $100 \mathrm{IU} / \mathrm{mL}$ penicillin (Sigma, USA), and $10 \mathrm{mg} / \mathrm{mL}$ streptomycin (Sigma, USA). The procedure used for the adherence assay followed that of Gopal et al. [19] with modifications. A cell suspension $(1 \times$ $10^{5}$ cell/mL DMEM) of Caco- 2 cells was used for preparation of a monolayer of the cells on glass cover slips placed in six-well tissue culture plates. One $\mathrm{mL}$ of the cell suspension was added into each well of the plates containing fresh 
DMEM, and the plates were incubated overnight. Incubation for maintenance of cells and adherence assay was at $37^{\circ} \mathrm{C}$ in $5 \% \mathrm{CO}_{2}$. For each LAB strain, cells from overnight culture $(10 \mathrm{~mL})$ were harvested by centrifugation at $4000 \times \mathrm{g}$ for $10 \mathrm{~min}$ at $4^{\circ} \mathrm{C}$, washed three times with sterile PBS ( $\mathrm{pH} 7.2$ ), and then resuspended in sterile PBS buffer $(\mathrm{pH} 7.2)$ to a final concentration of $8 \log \mathrm{CFU} / \mathrm{mL}$. Adherence assay was performed by adding $100 \mu \mathrm{L}$ of bacterial suspension onto the washed (once with PBS) monolayer of Caco- 2 cells in the well containing $2 \mathrm{~mL}$ of fresh DMEM and incubated for $1 \mathrm{~h}$ at $37^{\circ} \mathrm{C}$. After incubation, the monolayers were washed four times with PBS to remove unattached bacteria, then fixed with $3 \mathrm{~mL}$ of methanol, and incubated for 5 to $10 \mathrm{~min}$ at room temperature. The fixed monolayers were Gram stained and examined with a light microscope under oil immersion lens (Dialux, Leitz Wetzlar, Germany). Adherence was evaluated in 20 random microscopic fields and the number of adhered LAB cells per Caco- 2 cell was determined. The assay was performed twice, each in triplicate.

2.4. Antibiotic Susceptibility Test (Minimum Inhibitory Concentration). Antibiotic susceptibility test for the LAB strains was carried out using the broth microdilution method according to the ISO 10932/IDF 233 standard [20] with minor modifications. The antibiotics tested were ampicillin, clindamycin, gentamicin, streptomycin, tetracycline, erythromycin, kanamycin, and chloramphenicol (Sigma, USA). All the antibiotics were dissolved for preparing stock solutions of $1280 \mu \mathrm{g} / \mathrm{mL}$. The stock solutions were diluted in LAB susceptibility test medium (LSM) broth [21] to obtain solutions with concentrations of 0.25 to $128 \mu \mathrm{g} / \mathrm{mL}$. For preparation of bacterial inocula, colonies from overnight culture of each LAB strain were suspended in $5 \mathrm{~mL} 0.85 \%$ $\mathrm{NaCl}$ solution, adjusted to a turbidity of $0.2 \pm 0.02\left(\mathrm{OD}_{620 \mathrm{~nm}}\right)$, and diluted 1:500 in LSM broth. Then, $50 \mu \mathrm{L}$ of each diluted inoculum was added to each well of 96-well microdilution plates containing $50 \mu \mathrm{L}$ of an antibiotic solution, resulting in the concentration of about $5 \log \mathrm{CFU} /$ well for each bacterial inoculum. Inoculated plates were incubated anaerobically at $37^{\circ} \mathrm{C}$ for $48 \mathrm{~h}$. After incubation, the minimum inhibitory concentration (MIC) values were determined as the lowest concentration of an antibiotic in which visible growth was inhibited and were compared with the MIC breakpoint values for heterofermentative lactobacilli recommended by the European Food Safety Authority (EFSA) Panel on Additives and Products or Substances used in Animal Feed [22]. Accuracy of the test was checked by parallel use of a quality control strain (Enterococcus faecalis ATCC 29212) as suggested by the Clinical and Laboratory Standards Institute (CLSI) [23]. The assay was performed twice, each in triplicate.

\subsection{Antimicrobial Activity}

2.5.1. Antagonistic Activity against Pathogens. Twelve strains that are pathogenic to humans were used as test pathogens to investigate the antagonistic activity of the LAB strains. They were Candida albicans (ATCC 44831), Enterococcus faecium (ATCC 51558), Staphylococcus epidermidis (ATCC
12228), Propionibacterium acnes (ATCC 6919), E. coli (ATCC 29181), Shigella sonnei (ATCC 25931), and Helicobacter pylori (ATCC 43579) from the American type culture collection; Enterobacter cloacae, Vibrio parahaemolyticus, and Listeria monocytogenes were from the culture collection of Dr. Cheah Yoke Kqueen, Department of Biomedical Science, Faculty of Medicine and Health Science, Universiti Putra Malaysia; Klebsiella pneumoniae (K36) and Staphylococcus aureus (S244) were from the Institute of Medical Research, Malaysia.

The antagonistic activities of the LAB strains against the 12 pathogenic test strains were evaluated using the agar spot test described by Touré et al. [24] with modifications. Briefly, $2 \mu \mathrm{L}$ of overnight culture of each LAB strain (final concentration of $7 \log \mathrm{CFU} / \mathrm{mL}$ ) was spotted on MRS agar plates. The plates were dried for $30 \mathrm{~min}$ at room temperature and then incubated anaerobically at $37^{\circ} \mathrm{C}$ for $18 \mathrm{~h}$ in anaerobic jars (Oxoid, UK) containing gaspack (AnaeroGen, Oxoid, UK). After colony development, the plates were overlaid with $10 \mathrm{~mL}$ of soft $(0.8 \%$ (w/v) agar) microorganism-specific medium, seeded with $1 \%(\mathrm{v} / \mathrm{v})$ of an active overnight culture of the target pathogenic strain (final concentration of 7 log $\mathrm{CFU} / \mathrm{mL}$ ), and incubated aerobically at $37^{\circ} \mathrm{C}$, except for Candida albicans where the incubation temperature was $24^{\circ} \mathrm{C}$. The microorganism-specific media were yeast mold broth for Candida albicans (ATCC 44831), reinforced clostridial broth for Propionibacterium acnes (ATCC 6919), trypticase soy broth for Staphylococcus aureus (S244) and Enterococcus faecium (ATCC 51558), brain heart broth for Listeria monocytogenes, and nutrient broth for the other pathogenic strains (all media from Sigma, USA). After $48 \mathrm{~h}$ of incubation, measurements of inhibition zones around the LAB colonies were taken from the outer edge of the colonies to the outer edge of the clear zones. Inhibition zones of more than $20 \mathrm{~mm}$, 10 to $20 \mathrm{~mm}$, and less than $10 \mathrm{~mm}$ were considered as strong, intermediate, and low inhibitions, respectively. The test was performed twice, each in triplicate.

2.5.2. Characterization of Antimicrobial Substances. The LAB strains were assayed for production of antimicrobial substances such as bacteriocin, hydrogen peroxide, and organic acids using the agar well diffusion technique described by Touré et al. [24] with modifications. The bacterial strains were grown in $25 \mathrm{~mL}$ of MRS broth at $37^{\circ} \mathrm{C}$ overnight, after which the cultures were centrifuged at $4000 \times \mathrm{g}$ for $10 \mathrm{~min}$ at $4^{\circ} \mathrm{C}$. The supernatant of each strain was divided into equal portions for different assays. For bacteriocin assay, the supernatant $(5 \mathrm{~mL})$ was treated with $1 \mathrm{mg} / \mathrm{mL}$ trypsin (Sigma, USA) or $1 \mathrm{mg} / \mathrm{mL}$ pronase (Sigma, USA). For organic acids assay, the supernatant $(5 \mathrm{~mL})$ was adjusted to $\mathrm{pH} 6.5 \pm 0.1$ using $1 \mathrm{~N}$ $\mathrm{NaOH}$, and, for hydrogen peroxide assay, the supernatant $(5 \mathrm{~mL})$ was treated with $0.5 \mathrm{mg} / \mathrm{mL}$ catalase (Sigma, USA). Treated supernatants were filter sterilized through $0.22 \mu \mathrm{m}$ pore-size filters (Pall, USA), and $100 \mu \mathrm{L}$ was placed into wells (7 mm diameter) of MRS agar plates, overlaid with $10 \mathrm{~mL}$ of soft nutrient agar (Merck, Germany), and inoculated with $1 \%(\mathrm{v} / \mathrm{v})$ of an overnight culture of E. coli (ATCC 29181)as test pathogen (indicator strain). The plates were kept at $4^{\circ} \mathrm{C}$ 
for $3 \mathrm{~h}$ for better diffusion of the treated supernatant and then incubated for $48 \mathrm{~h}$ at $37^{\circ} \mathrm{C}$ and diameters of inhibition zones (including the $7 \mathrm{~mm}$ well diameter) were measured. The assays were carried out twice, each in triplicate.

2.5.3. Organic Acid Production Profile. Assays for organic acid production by the LAB strains were according to the method described by Erwin et al. [25] with modifications. Overnight culture (incubated at $37^{\circ} \mathrm{C}$ in anaerobic jar (Oxoid, UK) containing gaspack (AnaeroGen, Oxoid, UK, oxygen level $<1 \%, \mathrm{CO}_{2}$ level between 9 and $13 \%$ )) of each strain was centrifuged at $1500 \times \mathrm{g}$ for $10 \mathrm{~min}$ at room temperature and $3 \mathrm{~mL}$ of the supernatant was added to $600 \mu \mathrm{L}$ of $24 \%$ metaphosphoric acid (in $3 \mathrm{~N} \mathrm{H}_{2} \mathrm{SO}_{4}$ ). The mixture was kept at room temperature for $24 \mathrm{~h}$ and then centrifuged at $1500 \times \mathrm{g}$ for $20 \mathrm{~min}$ at room temperature. For volatile fatty acids (acetic, propionic, isobutyric, butyric, isovaleric, valeric, and caproic acids) (VFA) determination, $0.5 \mathrm{~mL}$ of supernatant was added with $0.5 \mathrm{~mL}$ of $20 \mathrm{mM} 4$-methylvaleric acid, and $1 \mu \mathrm{L}$ of each sample was injected to a gas chromatograph (GC, Agilent Technologies, USA) with a flame ionization detector (FID) and fused-silica capillary column $(30 \mathrm{~m} \times$ $25 \mu \mathrm{m}$, inside diameter). The temperature of column was set at 100 to $190^{\circ} \mathrm{C}$ with temperature programing at the rate of $5^{\circ} \mathrm{C} / \mathrm{min}$ increments for optimal separation. Temperatures of oven, FID, and injector were 160,250 , and $230^{\circ} \mathrm{C}$, respectively. Nitrogen with the flow rate of $1.0 \mathrm{~mL} / \mathrm{min}$ was used as carrier gas. The internal standard was $20 \mathrm{mM} 4$-methylvaleric acid. Acetic acid $(20 \mathrm{mM})$, propionic acid $(10 \mathrm{mM})$, butyric acid $(10 \mathrm{mM})$, isobutyric acid $(10 \mathrm{mM})$, valeric acid $(10 \mathrm{mM})$, isovaleric acid $(10 \mathrm{mM})$, and 4 -methylvaleric acid $(10 \mathrm{mM})$ were used as standard solutions to identify the peaks. For nonvolatile fatty acids (lactic and succinic acids) (non-VFA) determination, $0.5 \mathrm{~mL}$ of supernatant was added with $0.5 \mathrm{~mL}$ of $20 \mathrm{mM}$ fumaric acid and $1 \mu \mathrm{L}$ of each sample was injected to the GC. Temperatures of oven, FID, and injector were 180, 150 , and $110^{\circ} \mathrm{C}$, respectively. Nitrogen with the flow rate of $1.0 \mathrm{~mL} / \mathrm{min}$ was used as carrier gas. The internal standard was $20 \mathrm{mM}$ fumaric acid. Lactic acid (20 mM), succinic acid $(10 \mathrm{mM})$, and fumaric acid $(10 \mathrm{mM})$ were used as standard solutions to identify the peaks. The assays were carried out twice, each in triplicate.

2.6. Statistical Analysis. Data of each assay were analyzed by one-way analysis of variance (ANOVA) using the SAS (Statistical Analysis System, 2008) program version 9.2. Comparison among treatment means was performed using Duncan's new multiple range test. Differences were considered significant at $P<0.05$.

\section{Results}

3.1. Identification Using 16S rRNA Gene Sequences. The results of comparative $16 \mathrm{~S}$ rRNA gene analysis showed that all nine $\mathrm{LAB}$ isolates belonged to the genus Lactobacillus (Table 1). Of the three isolates from human milk, one isolate (HM1) was $99 \%$ similar to L. acidophilus while the other two isolates (HM2 and HM3) were 99\% similar to L. fermentum. One isolate (FG1) from fermented grapes and two isolates (FD1 and FD2) from fermented dates were $99 \%$ similar to L. buchneri. The three isolates (BF1, BF2, and BF3) from infant feces were $99 \%$ similar to L. casei. The $16 \mathrm{~S}$ rRNA gene sequences of the nine Lactobacillus strains were deposited in the GenBank database under the accession numbers JN188382 to JN188390 for isolates HM1, HM2, HM3, FG1, FD1, FD2, BF1, BF2, and $\mathrm{BF} 3$, respectively. The pure cultures of the nine Lactobacillus strains were deposited in the Microbial Culture Collection Unit (UNiCC) of Universiti Putra Malaysia under the accession numbers UPMC 999 to UPMC 1007 for isolates HM1, HM2, HM3, FG1, FD1, FD2, BF1, BF2, and BF3, respectively.

3.2. Phylogenetic Analysis Based on $16 S$ rRNA Gene. Figure 1 shows the phylogenetic tree based on 16S rRNA gene sequence analysis, depicting the phylogenetic relationships among the nine Lactobacillus strains and 41 Lactobacillus type strains obtained from the GenBank. Lactococcus lactis (AB100803.1) was used as the outgroup. Strains FD1 and FD2 isolated from fermented dates and FG1 isolated from fermented grapes were clustered together and were monophyletic with L. buchneri M58811.1 (bootstrap value of 78\%). The three strains, BF1, BF2, and BF3, isolated from infant feces, were grouped together and formed a monophyletic clade with L. casei AB008204.1 with a bootstrap value of 99\%. Two strains, HM2 and HM3, isolated from human milk, were monophyletic with L. fermentum AJ575812.1 with a remarkable bootstrap value of $100 \%$ and the other strain, HM1, also isolated from human milk, was monophyletic with L. acidophilus M58802.1, with a bootstrap value of $100 \%$.

\subsection{In Vitro Assessment of Characteristics for Survival in the Gastrointestinal Tract}

3.3.1. Acid, Bile, and Pancreatic Enzymes Tolerance. Table 2 shows the viability of the nine Lactobacillus strains isolated in this study and the reference strain $L$. casei Shirota at $\mathrm{pH}$ 3 and pH 7.2 (control). All nine Lactobacillus strains showed good tolerance to acid ( $\mathrm{pH} 3)$, but the level of tolerance varied among the strains. Of the nine Lactobacillus strains, eight ( $L$. acidophilus HM1, L. fermentum HM2 and HM3, L. buchneri FG1, FD1, and FD2, and L. casei BF1 and BF2) showed high acid tolerance with loss in cell viability of only 0.0 to $0.18 \mathrm{log}$ units. The acid tolerance levels of these Lactobacillus strains were significantly $(P<0.05)$ higher than those of $L$. casei BF3 with cell viability loss of $0.34 \mathrm{log}$ unit and the reference strain L. casei Shirota with loss in cell viability of 0.37 log unit.

The results of bile tolerance for all nine Lactobacillus strains and the reference strain are shown in Table 3. All nine Lactobacillus strains and the reference strain exhibited tolerance to $0.3 \%$ bile (oxgall). However, the degrees of tolerance varied among the strains. Lactobacillus acidophilus HM1, L. buchneri FG1, FD1, and FD2, and the reference strain L. casei Shirota showed the highest $(P<0.05)$ tolerance to bile salt, with an increase in cell viability of 0.01 and $0.02 \mathrm{log}$ units exhibited by L. acidophilus HM1 and L. buchneri FD2, respectively, and a slight reduction in cell viability of 0.01 to $0.04 \log$ units showed by L. casei Shirota and L. buchneri FG1 


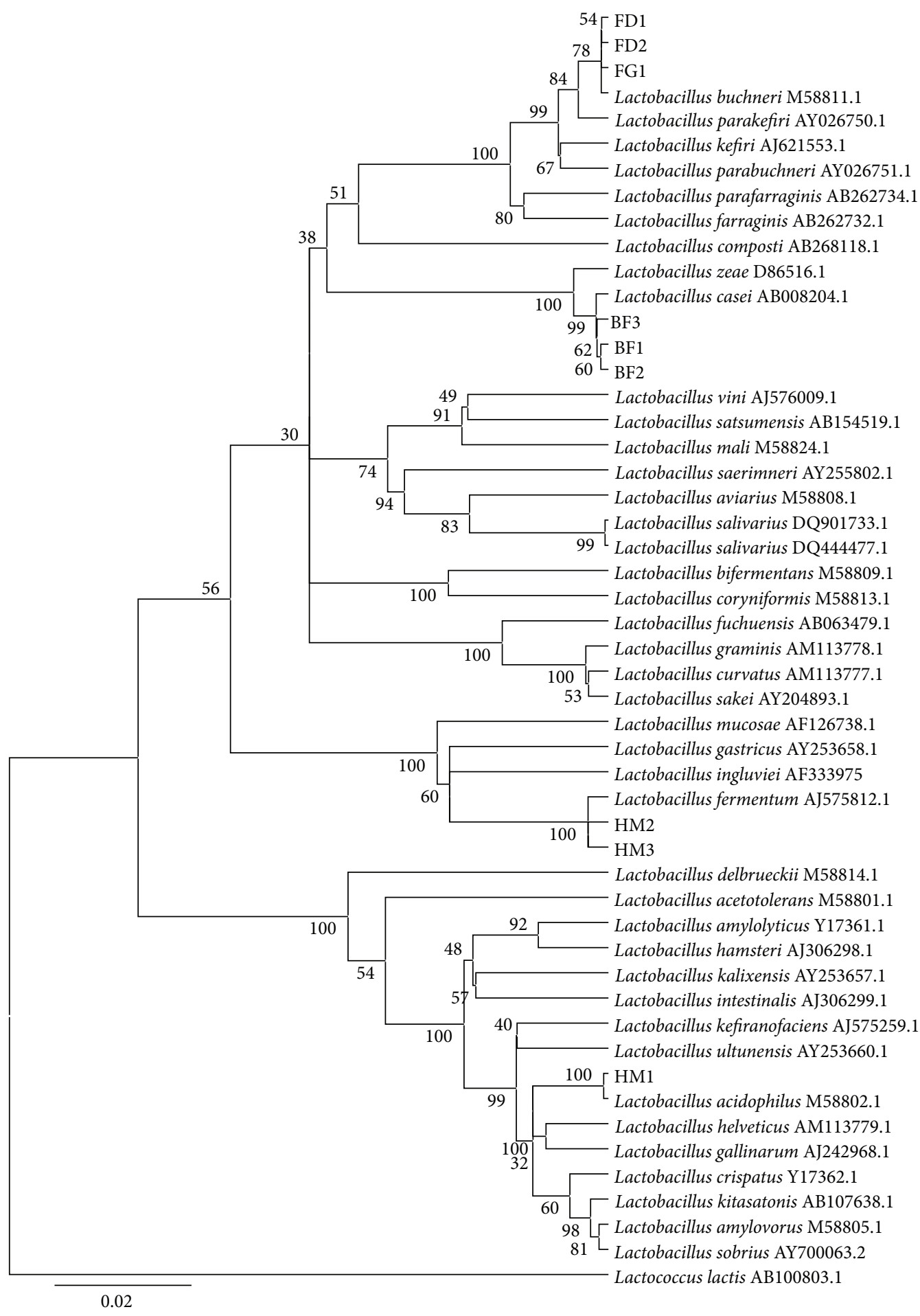

FIGURE 1: Phylogenetic tree based on the neighbor-joining method of $16 \mathrm{~S}$ rRNA gene sequences. The analysis involved nine sequences of Lactobacillus strains obtained in this study, 41 sequences of Lactobacillus species obtained from the GenBank, and the outgroup was Lactococcus lactis AB100803.1. Bootstrap values above $50 \%$ are indicated at the nodes of the tree. The scale bar represents 0.02 -nucleotide substitutes per position. 
TABLE 1: Identification of the nine lactic acid bacterial isolates using 16S rRNA gene sequences.

\begin{tabular}{|c|c|c|c|c|}
\hline Isolate & Source & Accession number of isolate & The nearest matched species from GenBank & Similarity (\%) \\
\hline HM1 & Human milk & JN188382 & L. acidophilus & 99 \\
\hline HM2 & Human milk & JN188383 & L. fermentum & 99 \\
\hline HM3 & Human milk & JN188384 & L. fermentum & 99 \\
\hline FG1 & Fermented grapes & JN188385 & L. buchneri & 99 \\
\hline FD1 & Fermented dates & JN188386 & L. buchneri & 99 \\
\hline FD2 & Fermented dates & JN188387 & L. buchneri & 99 \\
\hline BF1 & Infant feces & JN188388 & L. casei & 99 \\
\hline BF3 & Infant feces & JN188389 & L. casei & 99 \\
\hline BF2 & Infant feces & JN188390 & L. casei & 99 \\
\hline
\end{tabular}

Similarity values were determined using the basic local alignment search tool (BLAST) of the GenBank. Sequences with $\geq 97 \%$ similarity to the previously published sequences were used as the criteria to indicate species identity.

TABLE 2: Viability of Lactobacillus strains ( $\log \mathrm{CFU} / \mathrm{mL}$ ) after 3 h exposure to $\mathrm{pH} 3$ and $\mathrm{pH} 7.2$ (control).

\begin{tabular}{|c|c|c|c|}
\hline \multirow{2}{*}{ Lactobacillus strain } & \multicolumn{2}{|c|}{ Cell viability $(\log \mathrm{CFU} / \mathrm{mL})^{1}$} & \multirow{2}{*}{ Reduction in cell viability (log units) } \\
\hline & pH 7.2 & pH 3 & \\
\hline L. casei Shirota* & $7.11 \pm 0.07$ & $6.74 \pm 0.06$ & $0.37^{\mathrm{a}}$ \\
\hline L. acidophilus HM1 & $7.22 \pm 0.07$ & $7.15 \pm 0.06$ & $0.07^{\mathrm{bc}}$ \\
\hline L. fermentum HM2 & $7.30 \pm 0.03$ & $7.16 \pm 0.05$ & $0.14^{\mathrm{bc}}$ \\
\hline L. fermentum HM3 & $7.85 \pm 0.07$ & $7.69 \pm 0.10$ & $0.16^{\mathrm{bc}}$ \\
\hline L. buchneri FG1 & $6.97 \pm 0.03$ & $6.83 \pm 0.05$ & $0.14^{\mathrm{bc}}$ \\
\hline L. buchneri FD1 & $7.43 \pm 0.05$ & $7.25 \pm 0.03$ & $0.18^{\mathrm{b}}$ \\
\hline L. buchneri FD2 & $7.16 \pm 0.06$ & $7.16 \pm 0.04$ & $0.00^{c}$ \\
\hline L. casei $\mathrm{BF} 1$ & $7.30 \pm 0.03$ & $7.27 \pm 0.03$ & $0.03^{b c}$ \\
\hline L. casei BF2 & $7.48 \pm 0.08$ & $7.46 \pm 0.07$ & $0.02^{b c}$ \\
\hline L. casei $\mathrm{BF} 3$ & $7.12 \pm 0.05$ & $6.78 \pm 0.07$ & $0.34^{\mathrm{a}}$ \\
\hline
\end{tabular}

${ }^{1}$ Values are means \pm SD of two independent experiments, each with triplicate.

${ }^{\mathrm{a}-\mathrm{c}}$ Means within a column with different superscripts are significantly different $(P<0.05)$.

${ }^{*}$ Reference strain.

and FD1. The other Lactobacillus strains exhibited lower levels of tolerance to bile salt, with reduction in cell viability of 0.45 to $0.76 \log$ units.

All nine Lactobacillus strains and the reference strain exhibited good tolerance to pancreatic enzymes (Table 4). Lactobacillus buchneri FD2 was not affected at all by pancreatic enzymes, with no reduction in cell viability. Other strains such as L. acidophilus HM1, L. buchneri FG1 and FD1, L. casei BF2, and the reference strain L. casei Shirota showed high tolerance to pancreatic enzymes with reduction in cell viability of only 0.07 to $0.10 \mathrm{log}$ units. The two L. fermentum strains (HM2 and HM3) and two L. casei strains (BF1 and BF3) showed lower $(P<0.05)$ tolerance to the pancreatic enzymes with the reduction in cell viability of 0.15 to $0.27 \log$ units.

3.3.2. Adherence Ability. The adherence abilities of the Lactobacillus strains are shown in Table 5. All nine Lactobacillus strains and the reference strain were able to adhere to Caco2 cells, but the adherence ability varied widely among the strains. The highest $(P<0.05)$ adherence ability was exhibited by L. fermentum HM3 isolated from human milk, with 37.7 attached cells/Caco-2 cell, and the lowest $(P<$ 0.05 ) adherence ability was shown by L. casei BF1, with 13.7 attached cells/Caco-2 cell. Lactobacillus buchneri FD2 and FG1, L. acidophilus HM1, L. fermentum HM2, and L. buchneri FD1 with 35.9, 34.8, 33.5, 32.4, and 30.3 attached cells/Caco2 cell, respectively, also showed high attachment ability. The other two Lactobacillus strains (L. casei BF2 and BF3) and the reference strain $L$. casei Shirota had moderate adherence ability of 15.8 to 19.7 attached cells/Caco- 2 cell.

3.4. Antibiotic Susceptibility Test. The results of MIC values for antibiotic susceptibility of the Lactobacillus strains against eight tested antibiotics are shown in Table 6. All nine Lactobacillus strains and the reference strain exhibited MIC values lower than the MIC breakpoint values recommended for heterofermentative Lactobacillus strains by EFSA [22] for all the tested antibiotics, namely, ampicillin, gentamicin, kanamycin, streptomycin, erythromycin, clindamycin, tetracycline, and chloramphenicol. Vancomycin was not tested since all nine Lactobacillus strains and the reference strain were heterofermentative Lactobacillus strains, as, according to the EFSA [22], susceptibility testing of heterofermentative Lactobacillus strains against vancomycin is not required. In addition, since none of the strains was resistant to the tested antibiotics, no further studies on their antibiotic resistance are needed according to EFSA [22]. 
TABLE 3: Growth of Lactobacillus strains in MRS broth (control) and MRS broth containing $0.3 \%$ bile salt.

\begin{tabular}{|c|c|c|c|}
\hline \multirow{2}{*}{ Lactobacillus strain } & \multicolumn{2}{|c|}{ Cell viability $(\log \mathrm{CFU} / \mathrm{mL})^{1}$} & \multirow{2}{*}{ Reduction $(-)$ /increase $(+)$ in cell viability (log units $)^{1}$} \\
\hline & MRS & MRS $+0.3 \%$ bile salt & \\
\hline L. casei Shirota* & $8.75 \pm 0.13$ & $8.71 \pm 0.12$ & $-0.04^{\mathrm{a}}$ \\
\hline L. acidophilus HM1 & $7.40 \pm 0.31$ & $7.41 \pm 0.31$ & $+0.01^{\mathrm{a}}$ \\
\hline L. fermentum HM2 & $8.73 \pm 0.03$ & $8.04 \pm 0.04$ & $-0.69^{\mathrm{cd}}$ \\
\hline L. fermentum HM3 & $8.85 \pm 0.01$ & $8.17 \pm 0.05$ & $-0.68^{\mathrm{cd}}$ \\
\hline L. buchneri FG1 & $7.59 \pm 0.05$ & $7.56 \pm 0.07$ & $-0.03^{\mathrm{a}}$ \\
\hline L. buchneri FD1 & $7.53 \pm 0.05$ & $7.55 \pm 0.09$ & $+0.02^{\mathrm{a}}$ \\
\hline L. buchneri FD2 & $7.63 \pm 0.05$ & $7.62 \pm 0.11$ & $-0.01^{\mathrm{a}}$ \\
\hline L. casei $\mathrm{BF} 1$ & $8.25 \pm 0.02$ & $7.49 \pm 0.07$ & $-0.76^{\mathrm{d}}$ \\
\hline L. casei $\mathrm{BF} 2$ & $8.16 \pm 0.16$ & $7.71 \pm 0.06$ & $-0.45^{\mathrm{b}}$ \\
\hline L. casei $\mathrm{BF} 3$ & $8.08 \pm 0.16$ & $7.52 \pm 0.08$ & $-0.56^{\mathrm{bc}}$ \\
\hline
\end{tabular}

${ }^{1}$ Values are means \pm SD of two independent experiments, each with triplicate.

${ }^{\mathrm{a}-\mathrm{d}}$ Means within a column with different superscripts are significantly different $(P<0.05)$.

* Reference strain.

TABLE 4: Viability of Lactobacillus strains ( $\log \mathrm{CFU} / \mathrm{mL}$ ) after $3 \mathrm{~h}$ in PBS with and without (control) $1.9 \mathrm{mg} / \mathrm{mL}$ pancreatic enzymes.

\begin{tabular}{lccc}
\hline Lactobacillus strain & \multicolumn{2}{c}{$\begin{array}{c}\text { Cell viability }(\log \mathrm{CFU} / \mathrm{mL})^{1} \\
1.9 \mathrm{mg} / \mathrm{mL} \text { pancreatic enzymes }\end{array}$} & ${\text { Reduction in cell viability }(\log \text { units })^{1}}^{\text {Control }}$ \\
\hline L. casei Shirota & $7.81 \pm 0.09$ & $7.72 \pm 0.07$ & $0.09^{\mathrm{bc}}$ \\
L. acidophilus HM1 & $7.45 \pm 0.05$ & $7.33 \pm 0.07$ & $0.12^{\mathrm{bc}}$ \\
L. fermentum HM2 & $7.77 \pm 0.05$ & $7.50 \pm 0.08$ & $0.27^{\mathrm{a}}$ \\
L. fermentum HM3 & $7.97 \pm 0.04$ & $7.70 \pm 0.08$ & $0.27^{\mathrm{a}}$ \\
L. buchneri FG1 & $7.00 \pm 0.04$ & $6.90 \pm 0.04$ & $0.10^{\mathrm{bc}}$ \\
L. buchneri FD1 & $7.35 \pm 0.05$ & $7.28 \pm 0.07$ & $0.07^{\mathrm{bc}}$ \\
L. buchneri FD2 & $7.74 \pm 0.09$ & $7.74 \pm 0.03$ & $0.00^{\mathrm{c}}$ \\
L. casei BF1 & $7.88 \pm 0.04$ & $7.67 \pm 0.07$ & $0.21^{\mathrm{ab}}$ \\
L. casei BF2 & $7.28 \pm 0.11$ & $7.19 \pm 0.09$ & $0.09^{\mathrm{bc}}$ \\
L. casei BF3 & $7.76 \pm 0.07$ & $7.61 \pm 0.09$ & $0.15^{\mathrm{ab}}$
\end{tabular}

${ }^{1}$ Values are means \pm SD of two independent experiments, each with triplicate.

${ }^{\mathrm{a}-\mathrm{c}}$ Means within a column with different superscripts are significantly different $(P<0.05)$.

${ }^{*}$ Reference strain.

\subsection{Antimicrobial Activity}

3.5.1. Antagonistic Effects. The results of antagonistic effects of the Lactobacillus strains against 12 pathogenic strains are shown in Table 7. All nine Lactobacillus strains and the reference strain showed antagonistic effects against all pathogenic strains tested, but the degrees of antagonism varied among the Lactobacillus strains. The results showed that all the isolated Lactobacillus strains, except L. acidophilus HM1, exhibited strong inhibition on the growth of Staphylococcus epidermidis (ATCC12228), Enterobacter cloacae, and Listeria monocytogenes (inhibition zones of more than $20 \mathrm{~mm}$ ), and the three L. casei strains (BF1, BF2, and BF3) showed strong antagonistic activities against Helicobacter pylori (inhibition zones of more than $20 \mathrm{~mm}$ ) and good inhibition against Staphylococcus aureus (inhibition zones of 19 to $20 \mathrm{~mm}$ ). However, most of the Lactobacillus strains (including the reference strain) showed low inhibitory activities against Klebsiella pneumonia (K36) (inhibition zones of less than $10 \mathrm{~mm}$ ). Among the nine isolated Lactobacillus strains, $L$. case $\mathrm{BF} 1$ was the most effective strain in inhibiting the growth of the test pathogens. It showed the highest $(P<0.05)$ inhibitory actions against 8 of 12 test pathogens. In contrast, $L$. acidophilus $\mathrm{HM} 1$ was the least $(P<0.05)$ effective strain, showing the lowest inhibitory activities against 11 of 12 test pathogens. Overall, many of the isolated Lactobacillus strains showed better $(P<0.05)$ antagonistic activities against the test pathogens than the reference strain $L$. casei Shirota.

3.5.2. Characterization of Inhibitory Substances. The antimicrobial substance produced by the nine isolated Lactobacillus strains was characterized by the agar well diffusion assay against an indicator strain, E. coli (ATCC 29181). The results showed that culture supernatants of all nine isolated Lactobacillus strains and the reference strain treated with pronase $(1 \mathrm{mg} / \mathrm{mL})$ or trypsin $(1 \mathrm{mg} / \mathrm{mL})$ did not affect their inhibitory activities against the indicator strain (Table 8). This indicated that inhibitory effects of the Lactobacillus strains were not due to bacteriocin production. Culture supernatants treated with catalase also did not affect the inhibitory activities of the Lactobacillus strains against the indicator strain. This 
TABLE 5: Adherence of cells of Lactobacillus strains to Caco-2 cell.

\begin{tabular}{lc}
\hline Lactobacillus strain & $\begin{array}{c}\text { Adherence index } \\
\text { (Lactobacillus cells per } \\
\text { Caco-2 cell) }\end{array}$ \\
\hline L. casei Shirota & $19.7 \pm 0.3^{\mathrm{g}}$ \\
L. acidophilus $\mathrm{HM} 1$ & $33.5 \pm 0.9^{\mathrm{d}}$ \\
L. fermentum $\mathrm{HM} 2$ & $32.4 \pm 0.4^{\mathrm{e}}$ \\
L. fermentum $\mathrm{HM} 3$ & $37.7 \pm 0.6^{\mathrm{a}}$ \\
L. buchneri $\mathrm{FG1}$ & $34.8 \pm 0.5^{\mathrm{c}}$ \\
L. buchneri $\mathrm{FD} 1$ & $30.3 \pm 0.2^{\mathrm{f}}$ \\
L. buchneri $\mathrm{FD} 2$ & $35.9 \pm 0.7^{\mathrm{b}}$ \\
L. casei $\mathrm{BF} 1$ & $13.7 \pm 0.3^{\mathrm{j}}$ \\
L. casei $\mathrm{BF} 2$ & $18.5 \pm 0.3^{\mathrm{h}}$ \\
L. casei $\mathrm{BF} 3$ & $15.8 \pm 0.4^{\mathrm{i}}$ \\
\hline
\end{tabular}

${ }^{1}$ Values are means \pm SD of two independent experiments, each in triplicate. Adherence was evaluated in 20 random microscopic fields.

${ }^{\mathrm{a}-\mathrm{j}}$ Means with different superscripts are significantly different $(P<0.05)$.

${ }^{*}$ Reference strain.

showed that inhibition by the Lactobacillus strains was not due to hydrogen peroxide production. However, neutralized supernatants ( $\mathrm{pH}$ 6.5) of all Lactobacillus strains did not have any inhibitory activity against the indicator strain, which indicated that inhibitory effects of the Lactobacillus strains were due to their organic acid productions (Table 8).

3.5.3. Profile of Organic Acid Production. The organic acid production profiles of the Lactobacillus strains are presented in Table 9. Lactic acid was the most abundant organic acid produced by all the Lactobacillus strains, followed by acetic acid. The amounts of lactic acid produced varied among the strains, ranging from the lowest $(P<0.05)$ amount of $143.65 \mathrm{mM}$ produced by L. acidophilus HM1 to the highest amount of $356.95 \mathrm{mM}$ produced by $L$. casei BF1. Generally, all three strains of $L$. casei (BF1, BF2, and BF3) produced very high amounts of lactic acid (310.97 to $356.95 \mathrm{mM}$ ), while $L$. fermentum HM2 and HM3 and L. buchneri FD1 and FD2 produced more moderate amounts of 205.70 to $227.07 \mathrm{mM}$. Production of acetic acid also varied among the Lactobacillus strains. The highest $(P<0.05)$ amounts of acetic acid were produced by L. fermentum HM2 and HM3 and L. buchneri FG1 (with 130.14, 125.71, and $124.16 \mathrm{mM}$, resp.). The rest of the strains produced acetic acid ranging from 68.08 to $92.85 \mathrm{mM}$. Succinic acid production varied very widely among the Lactobacillus strains. Lactobacillus acidophilus HM1, L. fermentum HM2 and HM3, and L. buchneri FG1 produced more than $20 \mathrm{mM}$ of succinic acid, but the rest of the Lactobacillus strains produced about 1 to $2 \mathrm{mM}$. Other acids such as propionic, isobutyric, butyric, isovaleric, and caproic acids either were produced in trace amounts or were not produced by the Lactobacillus strains.

\section{Discussion}

In this study, nine Lactobacillus strains isolated from human milk (L. acidophilus HM1 and L. fermentum HM2 and HM3), infant feces (L. casei BF1, BF2, and BF3), fermented grapes (L. buchneri FG1), and fermented dates (L. buchneri FD1 and FD2) were evaluated for their potential probiotic characteristics and antimicrobial activity against some human pathogens.

Every potential probiotic strain is expected to tolerate the condition of the GIT in order to be able to provide its beneficial effect on the host. The ability to tolerate acid, bile, and pancreatic enzymes and to adhere to the intestinal epithelial cells has been considered as good indicator for the survival of a bacterial strain in the GIT, and these characteristics are often assessed in vitro in the preliminary selection of a probiotic strain. Although in vitro assessments may not be able to totally mimic the actual in situ conditions in the gut ecosystem, they remain powerful tools for rapid screening of potential strains. They permit an enormous level of simplification of the system under study, allowing a large number of strains to be investigated for a specific probiotic property. The use of in vivo studies for initial investigation of probiotic properties of new potential probiotic strains is not only time-consuming but also expensive. Thus, the use of in vitro assays to assess and select the most effective strain for in vivo investigations is a more logical option $[16,26]$. Dunne et al. [2] reported that adoption of proper criteria for the in vitro selection of probiotic bacteria can result in the isolation of strains capable of performing effectively in the GIT.

In the present study, $\mathrm{pH} 3$ was used to investigate the acid tolerance of the Lactobacillus strains as $\mathrm{pH} 3$ has been considered as a standard $\mathrm{pH}$ for investigation of acid tolerance of probiotic strains in many studies [27-30]. The results showed that all nine isolated Lactobacillus strains exhibited good acid tolerance at $\mathrm{pH} 3$ for $3 \mathrm{~h}$, with eight strains showing significantly better acid tolerance than the reference strain $L$. casei Shirota. Ehrmann et al. [16] also reported that strains of $L$. reuteri, $L$. salivarius, and $L$. animalis were able to tolerate $\mathrm{pH} 3$ for $4 \mathrm{~h}$, but the degrees of tolerance varied among the strains. Earlier, Charteris et al. [31] have pointed out in their review that most Lactobacillus spp. are able to tolerate $\mathrm{pH} 4$ for 1 hour, but the percentage of cell viability varies considerably among different strains. It is also apparent from the results of the current study that acid tolerance of the Lactobacillus strains was not related to the source of isolation as the level of acid tolerance could vary considerably among the strains from the same source. For example, among the three $L$. case $i$ strains isolated from infant feces, $L$. case $i \mathrm{BF} 3$ exhibited significantly lower acid tolerance than L. casei BF1 and BF2, and, between the two L. buchneri strains isolated from fermented dates, L. buchneri FD2 showed significantly higher acid tolerance than L. buchneri FD1.

The ability to tolerate bile salt at a concentration of $0.3 \%$ has a physiological significance because it is a level normally encountered in human intestine [32]. Gilliland et al. [33] have also reported that the normal concentration of bile salt in human small intestine is $0.3 \%(\mathrm{w} / \mathrm{v})$, but some studies have suggested that bile concentration is variable and unpredictable, changing according to diet composition and in a close relationship with the secretion of pancreatic enzymes $[34,35]$. However, in many studies, the standard level of $0.3 \%$ bile was considered for investigation of bile tolerance 
TABLE 6: Minimum inhibitory concentrations (MIC) for antibiotic susceptibility of Lactobacillus strains.

\begin{tabular}{|c|c|c|c|c|c|c|c|c|}
\hline \multirow[b]{2}{*}{ Strain } & \multicolumn{8}{|c|}{ Antibiotic [MIC $(\mu \mathrm{g} / \mathrm{mL})]$} \\
\hline & Ampicillin & Gentamicin & Kanamycin & Streptomycin & Erythromycin & Clindamycin & Tetracycline & Chloramphenicol \\
\hline Breakpoint ${ }^{*}$ & 4 & 16 & 64 & 64 & 1 & 1 & 8 & 4 \\
\hline L. casei Shirota** & $<0.25$ & $<8$ & $<64$ & $<32$ & $<1$ & $<0.063$ & $<1$ & $<4$ \\
\hline L. acidophilus HM1 & $<0.063$ & $<0.125$ & $<0.125$ & $<0.5$ & $<0.063$ & $<0.063$ & $<0.063$ & $<0.063$ \\
\hline L. fermentum HM2 & $<0.063$ & $<4$ & $<8$ & $<8$ & $<0.5$ & $<0.063$ & $<1$ & $<1$ \\
\hline L. fermentum HM3 & $<0.063$ & $<4$ & $<8$ & $<4$ & $<0.5$ & $<0.063$ & $<1$ & $<1$ \\
\hline L. buchneri FG1 & $<0.5$ & $<2$ & $<8$ & $<8$ & $<0.25$ & $<0.063$ & $<2$ & $<1$ \\
\hline L. buchneri FD1 & $<0.5$ & $<4$ & $<8$ & $<8$ & $<0.25$ & $<0.063$ & $<2$ & $<1$ \\
\hline L. buchneri FD2 & $<0.5$ & $<2$ & $<8$ & $<2$ & $<0.125$ & $<0.063$ & $<2$ & $<1$ \\
\hline L. casei BF1 & $<0.125$ & $<8$ & $<8$ & $<4$ & $<0.125$ & $<0.063$ & $<0.5$ & $<0.25$ \\
\hline L. casei BF2 & $<0.5$ & $<4$ & $<8$ & $<4$ & $<0.125$ & $<0.25$ & $<1$ & $<0.5$ \\
\hline L. casei BF3 & $<0.5$ & $<8$ & $<8$ & $<4$ & $<0.125$ & $<0.125$ & $<1$ & $<0.5$ \\
\hline
\end{tabular}

${ }^{*}$ Values are provided by EFSA [22] for facultative heterofermentative Lactobacillus strains; according to EFSA, susceptibility testing of heterofermentative Lactobacillus strains against vancomycin is not required.

${ }^{* *}$ Reference strain.

of potential probiotic Lactobacillus strains [17, 28, 30, 33, 36, 37]. Thus, in the present study, $0.3 \%$ bile concentration was used. All nine isolated Lactobacillus strains showed good bile tolerance at this concentration of bile salt. Similar results were reported by Kõll et al. [30] in which all 67 Lactobacillus strains tested exhibited tolerance at $0.3 \%$ bile. Jin et al. [38] also found that all 12 Lactobacillus strains tested were able to tolerate $0.3 \%$ of bile salt, while Jacobsen et al. [17] reported that 41 of 42 tested Lactobacillus strains could tolerate bile at this concentration.

In the current study, the degree of bile tolerance varied considerably with the strains. It was strain-specific and was not influenced by the environment of the isolation source. Kõll et al. [30] also found that the ability to tolerate bile salt was strain-specific among the tested Lactobacillus strains. Recently, Sahadeva et al. [28] also reported that $L$. acidophilus, L. casei Shirota, Streptococcus thermophilus, and Bifidobacterium from four brands of commercially cultured milk drinks showed a strain-specific profile of bile tolerance at $0.3 \%$ of bile salt.

Pancreatic enzymes are secreted into the small intestine through the pancreatic duct and they are involved in digestion of proteins, carbohydrates, and fats in foods. As such, some studies have included the ability to tolerate the presence of pancreatic enzymes as another criterion for selection of probiotic cultures $[18,39]$. In this study, $3 \mathrm{~h}$ of exposure to pancreatic enzymes had little adverse effect on the survival of the nine isolated Lactobacillus strains. All nine strains showed good tolerance to pancreatic enzymes, with slight variations in the degree of tolerance among the strains. Similar results were reported by Rönkä et al. [18] who found that $3 \mathrm{~h}$ of incubation in growth medium containing pancreatic enzymes had little effect on the viability of $L$. brevis strains. Ruiz-Moyano et al. [37] also reported that 46 out of 51 tested LAB strains survived after $3 \mathrm{~h}$ of treating with $1.9 \mathrm{mg} / \mathrm{mL}$ of pancreatic enzymes.

In addition to its ability to survive the stressful gastric environment of the GIT, every potential probiotic strain is also expected to be able to attach to the epithelial cells of the intestine in order to colonize and be established in the intestine [40]. Furthermore, high adherence to the intestine is necessary for releasing some probiotic bioeffects, for example, cholesterol lowering effects, immune-modulation, and antimicrobial activities against pathogens. Caco-2 cell line, which was used in this study, is a human intestinal cell line that has been extensively used as a cellular model for assessing attachment of bacteria because it has morphological and physiological characteristics of normal human enterocytes $[41,42]$. In the present study, adherence of the nine isolated Lactobacillus strains to the Caco- 2 cell line was in range of 14 to 38 cells per Caco- 2 cell. The adherence ability varied among the strains, indicating that it is strain-specific. Similar findings were reported by Jacobsen et al. [17] who studied 47 Lactobacillus strains for their ability to adhere to Caco2 cells and found considerable variations, from strong to low adhesion, among the strains. The strain-specific adhesion of Lactobacillus strains on different epithelial cell lines has been well documented by Del Piano et al. [43]. Gopal et al. [19] also found that L. rhamnosus DR20, L. acidophilus HN017, and B. lactis DR10 exhibited strong ability to adhere to the Caco-2 and HT29 human epithelial cell lines. Some studies indicated that exopolysaccharides on the cell walls are adhesion molecules which can affect the adherence ability of Lactobacillus strains $[44,45]$. It was also found that some adhesin factors of Lactobacillus strains are proteins that are loosely bound to surface components of epithelial cells by noncovalent interaction, such as electrostatic interaction [46].

According to EFSA [22], for the assessment of susceptibility of bacterial strains to antibiotics, serial twofold dilution methods should be used and relevant quality control strains should be included. In the dilution methods, the MIC is defined as the lowest concentration of the antibiotic that inhibits bacterial growth. In the present study, a serial twofold broth microdilution method was used to assess the susceptibility of the nine Lactobacillus strains to eight antibiotics suggested by EFSA [22] for heterofermentative Lactobacillus strains. The results showed that none of the 


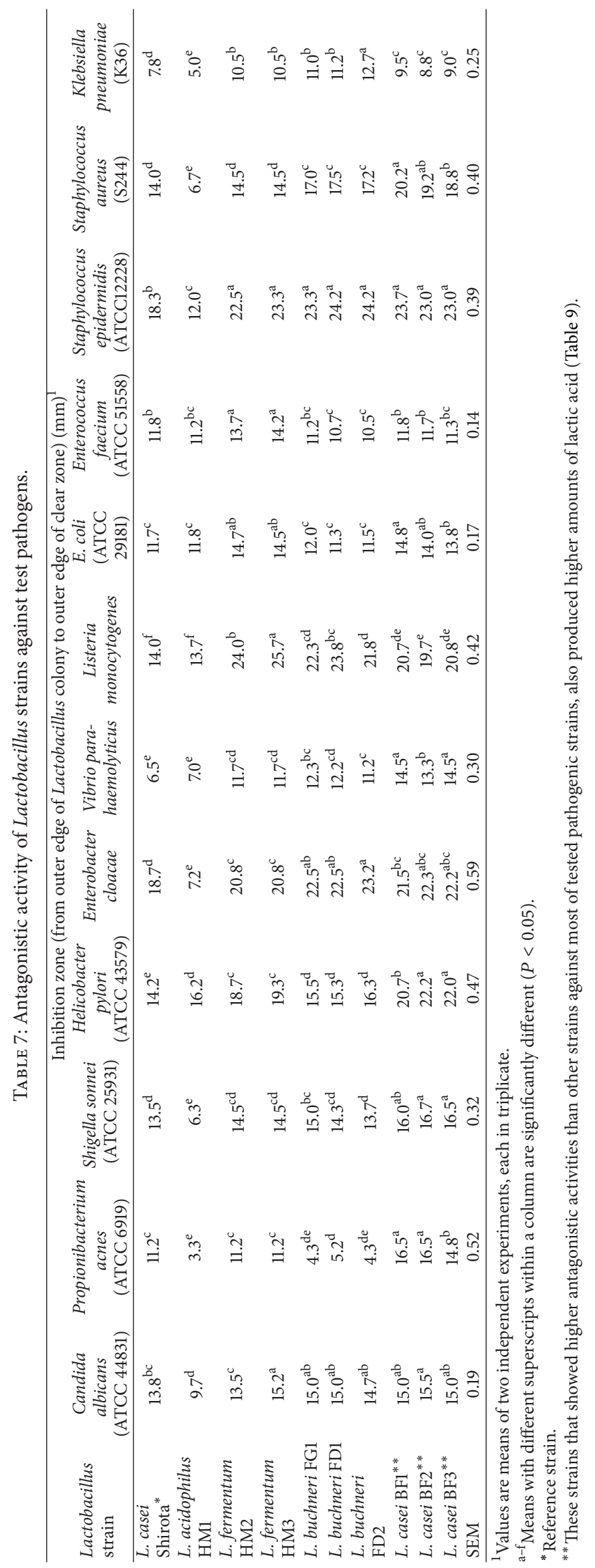


TABLE 8: Inhibitory activity of treated and untreated supernatants of Lactobacillus strains against E. coli (ATCC 29181) as indicator strain.

\begin{tabular}{|c|c|c|c|c|c|}
\hline \multirow{2}{*}{ Lactobacillus strain } & \multicolumn{5}{|c|}{ Diameter of inhibition zone $(\mathrm{mm})$ including $7 \mathrm{~mm}$ well diameter ${ }^{1}$} \\
\hline & $\begin{array}{c}\text { Untreated } \\
\text { supernatant (control) }\end{array}$ & $\begin{array}{c}\text { Neutralized } \\
\text { supernatant (pH 6.5) }\end{array}$ & $\begin{array}{c}\text { Supernatant }+ \\
\text { pronase }(1 \mathrm{mg} / \mathrm{mL})\end{array}$ & $\begin{array}{c}\text { Supernatant }+ \\
\text { trypsin }(1 \mathrm{mg} / \mathrm{mL})\end{array}$ & $\begin{array}{c}\text { Supernatant }+ \\
\text { catalase }(0.5 \mathrm{mg} / \mathrm{mL})\end{array}$ \\
\hline L. casei Shirota* & $16.9 \pm 0.8$ & - & $17.9 \pm 0.6$ & $17.1 \pm 0.0$ & $15.9 \pm 0.2$ \\
\hline L. acidophilus HM1 & $15.1 \pm 0.9$ & - & $14.5 \pm 2.1$ & $15.3 \pm 0.9$ & $14.8 \pm 0.2$ \\
\hline L. fermentum HM2 & $16.4 \pm 1.4$ & - & $15.7 \pm 1.4$ & $15.0 \pm 0.5$ & $17.0 \pm 1.9$ \\
\hline L. fermentum HM3 & $15.7 \pm 1.0$ & - & $15.5 \pm 0.7$ & $15.8 \pm 2.1$ & $15.5 \pm 1.6$ \\
\hline L. buchneri FG1 & $16.3 \pm 1.0$ & - & $16.8 \pm 0.2$ & $15.2 \pm 0.7$ & $16.5 \pm 1.2$ \\
\hline L. buchneri FD1 & $15.5 \pm 0.4$ & - & $16.0 \pm 0.5$ & $15.8 \pm 0.7$ & $15.2 \pm 0.2$ \\
\hline L. buchneri FD2 & $15.9 \pm 0.8$ & - & $17.2 \pm 1.2$ & $15.3 \pm 0.9$ & $15.3 \pm 1.4$ \\
\hline L. casei BF1 & $18.1 \pm 1.2$ & - & $17.8 \pm 0.2$ & $19.3 \pm 0.5$ & $17.7 \pm 0.5$ \\
\hline L. casei BF2 & $18.2 \pm 0.7$ & - & $18.0 \pm 0.9$ & $18.8 \pm 0.7$ & $17.8 \pm 0.2$ \\
\hline L. casei BF3 & $17.9 \pm 0.9$ & - & $18.5 \pm 0.2$ & $17.7 \pm 0.5$ & $17.8 \pm 0.7$ \\
\hline
\end{tabular}

${ }^{1}$ Values are means \pm SD of two independent experiments, each in triplicate.

- No inhibition.

${ }^{*}$ Reference strain.

nine Lactobacillus strains was resistant to any of the tested antibiotics. The results of antibiotic susceptibility of the quality control strain (Enterococcus faecalis ATCC 29212) were in the range suggested by CLSI [23], indicating the accuracy of the susceptibility testing.

Recently, Carasi et al. [47] examined six strains of $L$. kefiri for their susceptibility against eight antibiotics using the broth microdilution method and reported that all the strains were susceptible to tetracycline, clindamycin, streptomycin, ampicillin, erythromycin, kanamycin, and gentamicin, but two strains were resistant to chloramphenicol and were further studied for their chloramphenicol resistance gene. Mayrhofer et al. [48] also tested the susceptibility of 101 strains of the L. acidophilus group against 13 antibiotics using the broth microdilution method. They found narrow and broad unimodal and bimodal MIC distributions in the L. acidophilus group for the tested antimicrobial agents. Besides the microdilution method, diffusion methods such as Etest and disk diffusion have been used to assess the susceptibility of bacterial strains to antibiotics. Mayrhofer et al. [49] compared the results of the broth microdilution, disk diffusion, and Etest methods of 104 strains of the $L$. acidophilus group and reported that the MIC values obtained from the broth microdilution and the Etest methods were generally similar and they correlated with the inhibition zone diameters determined with the disk diffusion method. Korhonen et al. [50] also investigated 75 strains of L. rhamnosus for their susceptibility to six antibiotics using the agar dilution, broth microdilution, and Etest methods. They found that most of the tested strains were susceptible to ampicillin, clindamycin, erythromycin, gentamicin, streptomycin, and tetracycline, but three strains were resistant to clindamycin, erythromycin, and streptomycin, and one strain was resistant to streptomycin and tetracycline. Although qualitative or semiqualitative methods, such as the diffusion methods, are commonly used to determine MIC indirectly, at present, they are generally not acceptable by EFSA [22].
Antimicrobial activity against pathogens is another important attribute to be considered in the selection of potential probiotic strains for maintaining a healthy microbial balance in the GIT. In the present study, all nine isolated Lactobacillus strains showed antagonistic activity against all the 12 test pathogens, which are pathogenic to humans. Many of the Lactobacillus strains showed higher antagonistic effects against the test pathogens than the reference strain $L$. casei Shirota. In particular, the inhibitory effects of $L$. casei $\mathrm{BF} 1, \mathrm{BF} 2$, and $\mathrm{BF} 3$ on $H$. pylori and S. aureus were significantly higher than those of $L$. casei Shirota. Helicobacter pylori infection of the stomach can cause chronic gastritis, gastric or duodenal ulcers, and gastric cancer. Treatment of H. pylori infection using multiple antibiotic regimens may not eradicate it effectively and reinfection may occur. New treatment strategies such as using probiotic strains to reduce the growth of $H$. pylori in humans have been considered. Cats et al. [51] had reported that L. casei Shirota, which was used as a reference strain in the present study, was capable of inhibiting the growth of $H$. pylori in vitro, and in vivo (in human subjects), there was a slight, but nonsignificant, trend towards an inhibitory effect of $L$. casei Shirota on H. pylori. The three L. casei strains (BF1, BF2, and BF3) which showed significantly higher inhibitory effect than L. casei Shirota in the current study should be further studied, as they may be more promising biotherapeutic agents for $H$. pylori infection than L. casei Shirota. Similarly, further investigation on $L$. casei $\mathrm{BF} 1, \mathrm{BF} 2$, and BF3 should be conducted to explore their potential as biotherapeutic agents for $S$. aureus infection. It is well known that $S$. aureus has become resistant to multiple antibiotics, and new therapeutic agents are required.

The concept of antagonistic activity of LAB against pathogenic strains has been well documented in a review by Šušković et al. [52]. The antagonistic activity has mostly been attributed to the production of antimicrobial substances or metabolites such as organic acids, hydrogen peroxide, ethanol, diacetyl, acetaldehyde, acetoin, carbon dioxide, reuterin, reutericyclin, and bacteriocins by the probiotic 


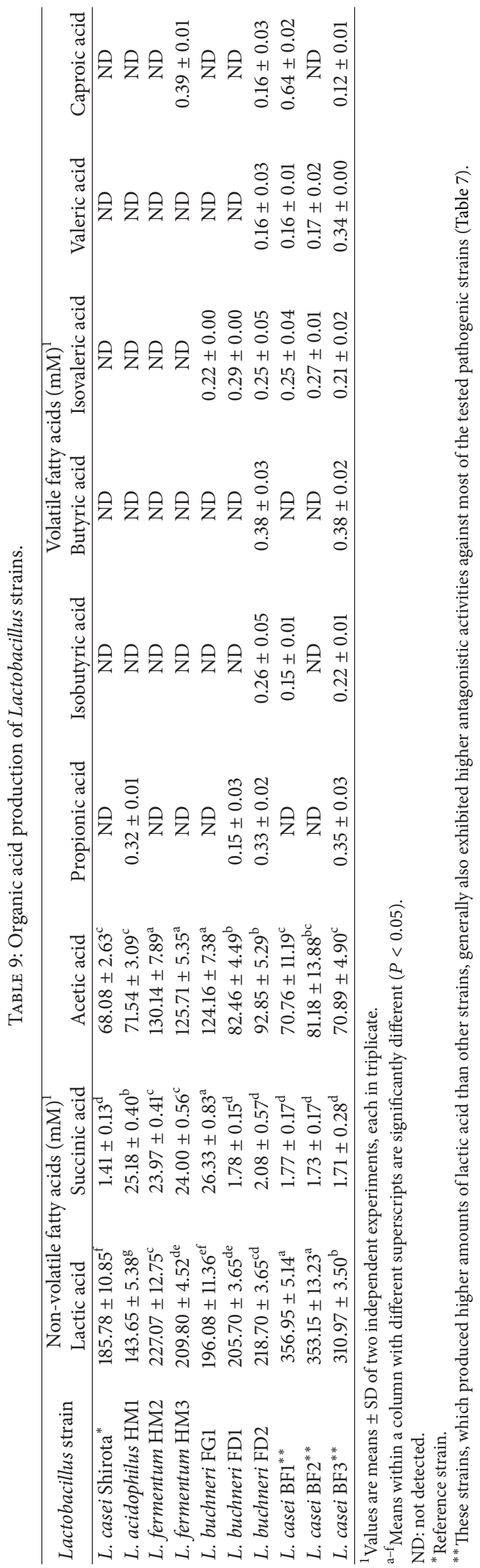


strains. This activity, together with the mechanism of competitive exclusion, in which probiotic strains compete with pathogens for nutrients and attachment sites, would prevent colonization of the intestine by pathogens [53]. Among the antimicrobial substances, organic acids (especially lactic and acetic acids), hydrogen peroxide, and bacteriocins are the most common antimicrobial substances that have been reported to be produced by probiotic strains. In the current study, the antagonistic activities of all nine isolated Lactobacillus strains were found to be due to their organic acid production not hydrogen peroxide or bacteriocin production. Jin [54] had also found that the inhibitory effects of 12 Lactobacillus strains on pathogenic Salmonella and E. coli were due to their production of organic acids. Recently, NealMcKinney et al. [55] reported that the antagonistic activities of L. acidophilus, L. crispatus, L. gallinarum, and L. helveticus against six strains of Campylobacter jejuni were due to organic acid production not bacteriocin production.

The organic acid profiles of the nine Lactobacillus strains in the present study showed that lactic acid was the predominant acid produced by all the strains, followed by acetic acid, and succinic acid was produced in much lesser amount. The other acids, such as propionic, butyric, isobutyric, valeric, and isovaleric acids, were either not produced or produced in trace amounts by some of the strains. It has been reported that lactic and acetic acids are the main organic acids involved in antimicrobial activity of Lactobacillus strains [56]. The antifungal activities of lactic and acetic acids produced by lactobacilli against Aspergilli and Fusarium were investigated by Zalan et al. [57] and they reported that none of the investigated Aspergilli was inhibited, but the inhibitory effect of the acids against Fusarium increased with increasing concentrations of acids. They also reported that the production of organic acids varied between species and also between strains of the same subspecies of 10 tested strains of L. casei, L. rhamnosus, L. plantarum, L. paracasei, and L. curvatus. Species- and strain-specific antimicrobial activities of lactobacilli have also been reported by Corsetti et al. [58] who tested 232 strains from nine species of Lactobacillus isolated from sourdoughs for their antagonistic activity against sourdough-related microorganisms. Of these, 77 strains showed antagonistic activity with a clear speciesand strain-specific profile. Similarly, the results of the present study showed that the antagonistic activities and production of organic acids varied among the nine Lactobacillus strains and were strain-specific. The effectiveness of the Lactobacillus strain in inhibiting the test pathogens generally corresponded with the amounts of organic acids produced, particularly lactic acid. For instance, $L$. casei BF1, which was the most effective strain in inhibiting the growth of the test pathogens, produced more than twice the amount of lactic acid when compared to L. acidophilus HM1, which was the least effective strain.

\section{Conclusions}

The results of this in vitro study indicated that all nine Lactobacillus strains were able to survive in the GIT and attached to the epithelial cells, while none of them was antibiotic resistant. Since all nine Lactobacillus strains showed strong antagonistic activities against a wide range of pathogens to humans, they could be considered as good potential probiotic candidates for treatment and prevention of infections. They should be studied further as biotherapeutic agents for treatments of specific disease conditions. The strains should also be investigated further for other probiotic bioactivities that have human health benefits.

\section{Conflict of Interests}

The authors declare that they do not have any conflict of interests with any third party receiving any financial gain from this study.

\section{Acknowledgment}

This study was supported by the Ministry of Education, Malaysia, under the Long Term Research Grant Scheme (600RMI/LRGS 5/3 (2/2012)).

\section{References}

[1] FAO/WHO, "Health and nutritional properties of probiotics in food including powder milk with live lactic acid bacteria: report of a Joint FAO/WHO expert consultation on evaluation of health and nutritional properties of probiotics in food including powder milk with live lactic acid bacteria," Tech. Rep., Food and Agriculture Organization/World Health Organization, Cordoba, Argentina, 2001, http://www.who.int/foodsafety/publications/fs_management/en/probiotics.pdf.

[2] C. Dunne, L. O’Mahony, L. Murphy et al., "In vitro selection criteria for probiotic bacteria of human origin: correlation with in vivo findings," The American Journal of Clinical Nutrition, vol. 73, no. 2, pp. 386-392, 2001.

[3] J. M. T. Hamilton-Miller, S. Shah, and C. T. Smith, "Probiotic' remedies are not what they seem," The British Medical Journal, vol. 312, no. 7022, pp. 55-56, 1996.

[4] J. M. T. Hamilton-Miller, S. Shah, and J. T. Winkler, "Public health issues arising from microbiological and labelling quality of foods and supplements containing probiotic microorganisms," Public Health Nutrition, vol. 2, no. 2, pp. 223-229, 1999.

[5] F. Canganella, S. Paganini, M. Ovidi et al., "A microbiological investigation on probiotic pharmaceutical products used for human health," Microbiological Research, vol. 152, no. 2, pp. 171$179,1997$.

[6] G. Klein, A. Pack, C. Bonaparte, and G. Reuter, "Taxonomy and physiology of probiotic lactic acid bacteria," International Journal of Food Microbiology, vol. 41, no. 2, pp. 103-125, 1998.

[7] U. Schillinger, "Isolation and identification of lactobacilli from novel-type probiotic and mild yoghurts and their stability during refrigerated storage," International Journal of Food Microbiology, vol. 47, no. 1-2, pp. 79-87, 1999.

[8] FAO/WHO, "Guidelines for the evaluation of probiotics in food," Report of a Joint FAO/WHO Working Group on Drafting Guidelines for the Evaluation of Probiotics in Food, Food and Agriculture Organization/World Health Organization, London, UK, Ontario, Canada, 2002, ftp://ftp.fao.org/es/esn/food/wgreport2.pdf. 
[9] I. R. McDonald, E. M. Kenna, and J. C. Murrell, "Detection of methanotrophic bacteria in environmental samples with the PCR," Applied and Environmental Microbiology, vol. 61, no. 1, pp. 116-121, 1995.

[10] D. J. Lane, "16S/23S rRNA sequencing," in Nucleic Acid Techniques in Bacterial Systematics, E. Stackebrandt and M. Goodfellow, Eds., John Wiley and Sons, 1991.

[11] T. A. Hall, "BioEdit: a user-friendly biological sequence alignment and analysis program for Windows 95/98/NT," Nucleic Acids Symposium Series, vol. 41, pp. 95-98, 1999.

[12] NCBI, National Center for Biotechnology Information.

[13] K. Tamura, "Estimation of the number of nucleotide substitutions when there are strong transition-transversion and $\mathrm{G}+\mathrm{C}$ content biases," Molecular Biology and Evolution, vol. 9, no. 4, pp. 678-687, 1992.

[14] K. E. Ashelford, N. A. Chuzhanova, J. C. Fry, A. J. Jones, and A. J. Weightman, "At least 1 in $2016 \mathrm{~S}$ rRNA sequence records currently held in public repositories is estimated to contain substantial anomalies," Applied and Environmental Microbiology, vol. 71, no. 12, pp. 7724-7736, 2005.

[15] T. Huber, G. Faulkner, and P. Hugenholtz, "Bellerophon: a program to detect chimeric sequences in multiple sequence alignments," Bioinformatics, vol. 20, no. 14, pp. 2317-2319, 2004.

[16] M. A. Ehrmann, P. Kurzak, J. Bauer, and R. F. Vogel, "Characterization of lactobacilli towards their use as probiotic adjuncts in poultry," Journal of Applied Microbiology, vol. 92, no. 5, pp. 966-975, 2002.

[17] C. N. Jacobsen, V. R. Nielsen, A. E. Hayford et al., "Screening of probiotic activities of forty-seven strains of Lactobacillus spp. by in vitro techniques and evaluation of the colonization ability of five selected strains in humans," Applied and Environmental Microbiology, vol. 65, no. 11, pp. 4949-4956, 1999.

[18] E. Rönkä, E. Malinen, M. Saarela, M. Rinta-Koski, J. Aarnikunnas, and A. Palva, "Probiotic and milk technological properties of Lactobacillus brevis," International Journal of Food Microbiology, vol. 83, no. 1, pp. 63-74, 2003.

[19] P. K. Gopal, J. Prasad, J. Smart, and H. S. Gill, “In vitro adherence properties of Lactobacillus rhamnosus DR20 and Bifidobacterium lactis DR10 strains and their antagonistic activity against an enterotoxigenic Escherichia coli," International Journal of Food Microbiology, vol. 67, no. 3, pp. 207-216, 2001.

[20] ISO: International Organization for Standardization, "Milk and milk products-Determination of the minimal inhibitory concentration (MIC) of antibiotics applicable to bifidobacteria and non-enterococcal lactic acid bacteria (LAB)," ISO 10932/IDF 233 standard, 2010.

[21] I. Klare, C. Konstabel, S. Müller-Bertling et al., "Evaluation of new broth media for microdilution antibiotic susceptibility testing of lactobacilli, pediococci, lactococci, and bifidobacteria," Applied and Environmental Microbiology, vol. 71, no. 12, pp. 8982-8986, 2005.

[22] "EFSA panel on additives and products or substances used in animal feed, guidance on the assessment of bacterial susceptibility to antimicrobials of human and veterinary importance," EFSA Journal, vol. 10, pp. 1-10, 2012.

[23] M. A. Wikler, "Performance standards for antimicrobial susceptibility testing," in Performance Standards for Antimicrobial Susceptibility Testing. Seventeenth Informational Supplement, CLSI Document M100-S17, Clinical and Laboratory Standards Institute, Wayne, NJ, USA, 2007.

[24] R. Touré, E. Kheadr, C. Lacroix, O. Moroni, and I. Fliss, "Production of antibacterial substances by bifidobacterial isolates from infant stool active against Listeria monocytogenes," Journal of Applied Microbiology, vol. 95, no. 5, pp. 1058-1069, 2003.

[25] E. S. Erwin, G. J. Marco, and E. M. Emery, "Volatile fatty acid analyses of blood and rumen fluid by gas chromatography," Journal of Dairy Science, vol. 44, no. 9, pp. 1768-1771, 1961.

[26] R. Nemcová, "Selection criteria of lactobacilli for probiotic use," Veterinarni Medicina, vol. 42, no. 1, pp. 19-27, 1997.

[27] M. T. Liong and N. P. Shah, "Acid and bile tolerance and cholesterol removal ability of lactobacilli strains," Journal of Dairy Science, vol. 88, no. 1, pp. 55-66, 2005.

[28] R. P. K. Sahadeva, S. F. Leong, K. H. Chua et al., "Survival of commercial probiotic strains to $\mathrm{pH}$ and bile," International Food Research Journal, vol. 18, no. 4, pp. 1515-1522, 2011.

[29] E. S. Chan and Z. Zhang, "Bioencapsulation by compression coating of probiotic bacteria for their protection in an acidic medium," Process Biochemistry, vol. 40, no. 10, pp. 3346-3351, 2005.

[30] P. Kõll, R. Mändar, H. Marcotte, E. Leibur, M. Mikelsaar, and L. Hammarström, "Characterization of oral lactobacilli as potential probiotics for oral health," Oral Microbiology and Immunology, vol. 23, no. 2, pp. 139-147, 2008.

[31] W. P. Charteris, P. M. Kelly, L. Morelli, and J. K. Collins, "Development and application of an in vitro methodology to determine the transit tolerance of potentially probiotic Lactobacillus and Bifidobacterium species in the upper human gastrointestinal tract," Journal of Applied Microbiology, vol. 84, no. 5, pp. 759-768, 1998.

[32] J. Sjovall, "On the concentration of bile acids in the human intestine during absorption. Bile acids and sterioids 74," Acta Physiologica Scandinavica, vol. 46, pp. 339-345, 1959.

[33] S. E. Gilliland, T. E. Staley, and L. J. Bush, "Importance of bile tolerance of Lactobacillus acidophilus used as a dietary adjunct," Journal of Dairy Science, vol. 67, no. 12, pp. 3045-3051, 1984.

[34] W. E. V. Lankaputhra and N. P. Shah, "Survival of Lactobacillus acidophilus and Bifidobacterium spp in the presence of acid and bile salts," Cultured Dairy Products Journal, vol. 30, pp. 2-7, 1995.

[35] A. Knarreborg, S. K. Jensen, and R. M. Engberg, "Pancreatic lipase activity as influenced by unconjugated bile acids and $\mathrm{pH}$, measured in vitro and in vivo," Journal of Nutritional Biochemistry, vol. 14, no. 5, pp. 259-265, 2003.

[36] P. Boonkumklao, P. Kongthong, and A. Assavanig, "Acid and bile tolerance of Lactobacillus thermotolerans, a novel species isolated from chicken feces," Kasetsart Journal: Natural Science, vol. 40, pp. 13-17, 2006.

[37] S. Ruiz-Moyano, A. Martín, M. J. Benito, F. P. Nevado, and M. de Guía Córdoba, "Screening of lactic acid bacteria and bifidobacteria for potential probiotic use in Iberian dry fermented sausages," Meat Science, vol. 80, no. 3, pp. 715-721, 2008.

[38] L. Z. Jin, Y. W. Ho, N. Abdullah, and S. Jalaludin, "Acid and bile tolerance of Lactobacillus isolated from chicken intestine," Letters in Applied Microbiology, vol. 27, no. 3, pp. 183-185, 1998.

[39] S. Salminen, A. von Wright, L. Morelli et al., "Demonstration of safety of probiotics-a review," International Journal of Food Microbiology, vol. 44, no. 1-2, pp. 93-106, 1998.

[40] Y. K. Lee and S. Salminen, "The coming of age of probiotics," Trends in Food Science and Technology, vol. 6, no. 7, pp. 241-245, 1995.

[41] E. M. Tuomola and S. J. Salminen, "Adhesion of some probiotic and dairy Lactobacillus strains to Caco-2 cell cultures," International Journal of Food Microbiology, vol. 41, no. 1, pp. 45-51, 1998. 
[42] M. Pinto, S. Robine Leon, M. D. Appay et al., "Enterocyte-like differentiation and polarization of the human colon carcinoma cell line Caco-2 in culture," Biology of the Cell, vol. 47, no. 3, pp. 323-330, 1983.

[43] M. Del Piano, L. Morelli, G. P. Strozzi et al., "Probiotics: from research to consumer," Digestive and Liver Disease, vol. 38, no. 2, pp. 248-255, 2006.

[44] R. Tallon, P. Bressollier, and M. C. Urdaci, "Isolation and characterization of two exopolysaccharides produced by Lactobacillus plantarum EP56," Research in Microbiology, vol. 154, no. 10, pp. 705-712, 2003.

[45] L. de Vuyst and B. Degeest, "Heteropolysaccharides from lactic acid bacteria," FEMS Microbiology Reviews, vol. 23, no. 2, pp. 153-177, 1999.

[46] G. E. Bergonzelli, D. Granato, R. D. Pridmore, L. F. MarvinGuy, D. Donnicola, and I. E. Corthésy-Theulaz, "GroEL of Lactobacillus johnsonii Lal (NCC 533) is cell surface associated: potential role in interactions with the host and the gastric pathogen Helicobacter pylori," Infection and Immunity, vol. 74, no. 1, pp. 425-434, 2006.

[47] P. Carasi, M. Díaz, S. M. Racedo et al., "Safety characterization and antimicrobial properties of kefir-isolated Lactobacillus kefiri," BioMed Research International, vol. 2014, Article ID 208974, 7 pages, 2014.

[48] S. Mayrhofer, A. H. A. M. van Hoek, C. Mair et al., "Antibiotic susceptibility of members of the Lactobacillus acidophilus group using broth microdilution and molecular identification of their resistance determinants," International Journal of Food Microbiology, vol. 144, no. 1, pp. 81-87, 2010.

[49] S. Mayrhofer, K. J. Domig, C. Mair, U. Zitz, G. Huys, and W. Kneifel, "Comparison of broth microdilution, Etest, and agar disk diffusion methods for antimicrobial susceptibility testing of Lactobacillus acidophilus group members," Applied and Environmental Microbiology, vol. 74, no. 12, pp. 3745-3748, 2008.

[50] J. Korhonen, A. A. van Hoek, M. Saarela et al., "Antimicrobial susceptibility of Lactobacillus rhamnosus," Beneficial Microbes, vol. 1, no. 1, pp. 75-80, 2010.

[51] A. Cats, E. J. Kuipers, M. A. R. Bosschaert, R. G. J. Pot, C. M. J. E. Vandenbroucke-Grauls, and J. G. Kusters, "Effect of frequent consumption of a Lactobacillus casei-containing milk drink in Helicobacter pylori-colonized subjects," Alimentary Pharmacology and Therapeutics, vol. 17, no. 3, pp. 429-435, 2003.

[52] J. Šušković, K. Blazenka, J. Beganović, A. L. Pavunc, K. Habjanič, and S. Matosic, "Antimicrobial activity-the most important property of probiotic and starter lactic acid bacteria," Food Technology and Biotechnology, vol. 48, no. 3, pp. 296-307, 2010.

[53] D. M. Saulnier, J. K. Spinler, G. R. Gibson, and J. Versalovic, "Mechanisms of probiosis and prebiosis: considerations for enhanced functional foods," Current Opinion in Biotechnology, vol. 20, no. 2, pp. 135-141, 2009.

[54] L. Z. Jin, Studies on the mechanisms and utilization of probiotics (direct-fed microbials) in broilers [Ph.D. thesis], University Putra Malaysia, Kuala Lumpur, Malaysia, 1996.

[55] J. M. Neal-McKinney, X. Lu, T. Duong et al., "Production of organic acids by probiotic lactobacilli can be used to reduce pathogen load in poultry," PLoS ONE, vol. 7, no. 9, Article ID e43928, 2012.

[56] A. Corsetti, M. Gobbetti, J. Rossi, and P. Damiani, "Antimould activity of sourdough lactic acid bacteria: identification of a mixture of organic acids produced by Lactobacillus sanfrancisco CB1," Applied Microbiology and Biotechnology, vol. 50, no. 2, pp. 253-256, 1998.

[57] Z. Zalan, J. Hudacek, J. Stetina, J. Chumchalova, and A. Halasz, "Production of organic acids by Lactobacillus strains in three different media," European Food Research and Technology, vol. 230, pp. 395-404, 2010.

[58] A. Corsetti, M. Gobbetti, and E. Smacchi, "Antibacterial activity of sourdough lactic acid bacteria: isolation of a bacteriocin-like inhibitory substance from Lactobacillus sanfrancisco C57," Food Microbiology, vol. 13, no. 6, pp. 447-456, 1996. 

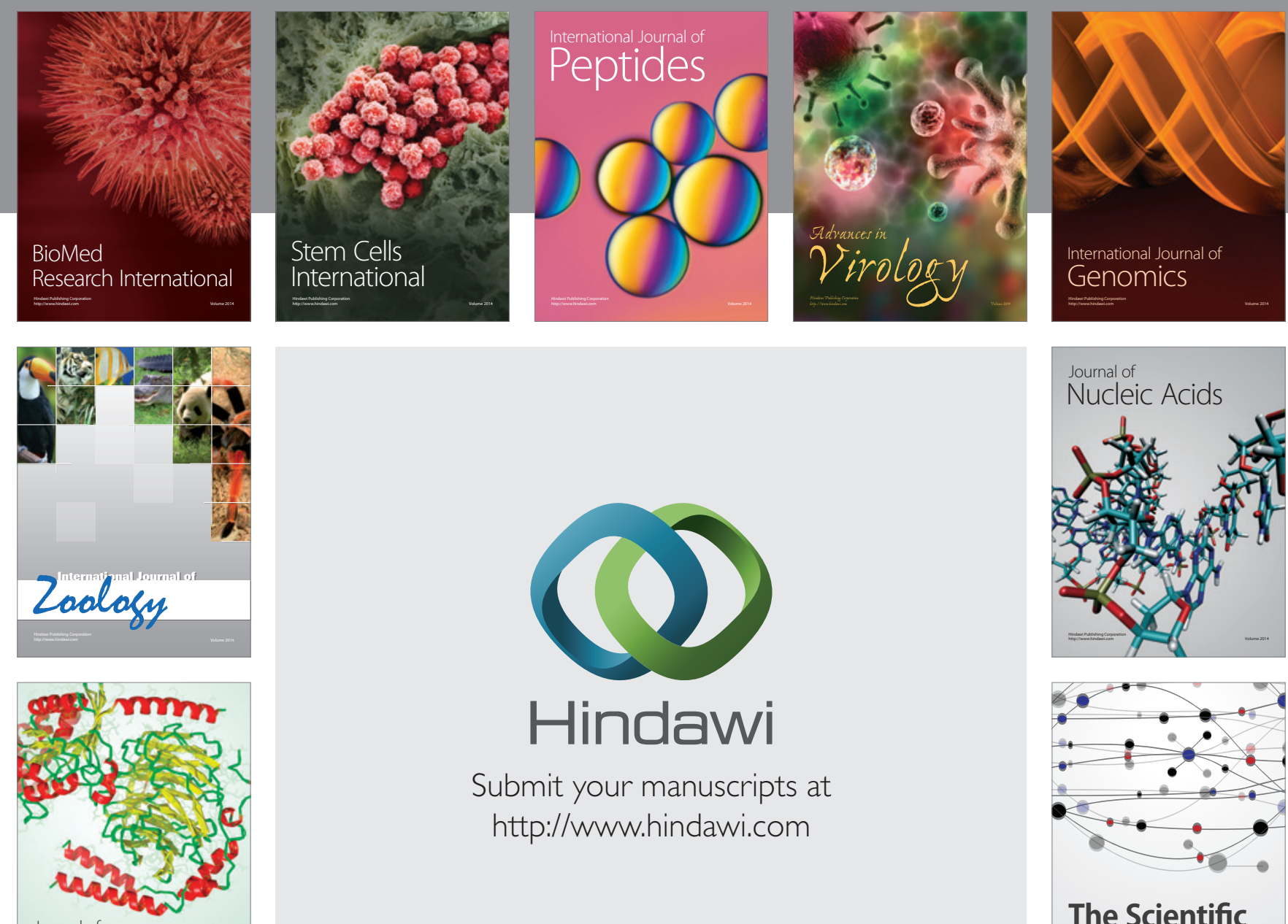

Submit your manuscripts at

http://www.hindawi.com

Journal of
Signal Transduction
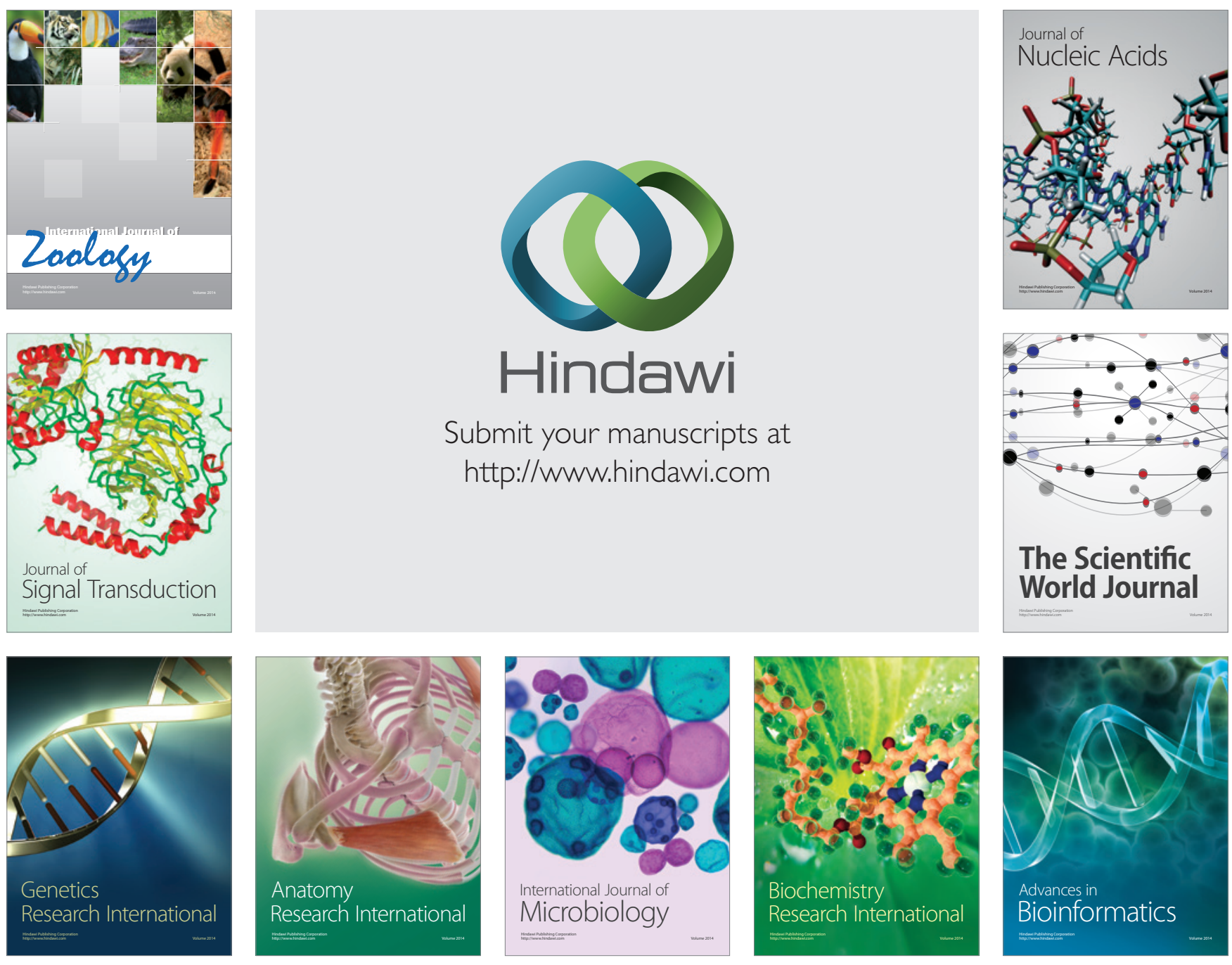

The Scientific World Journal
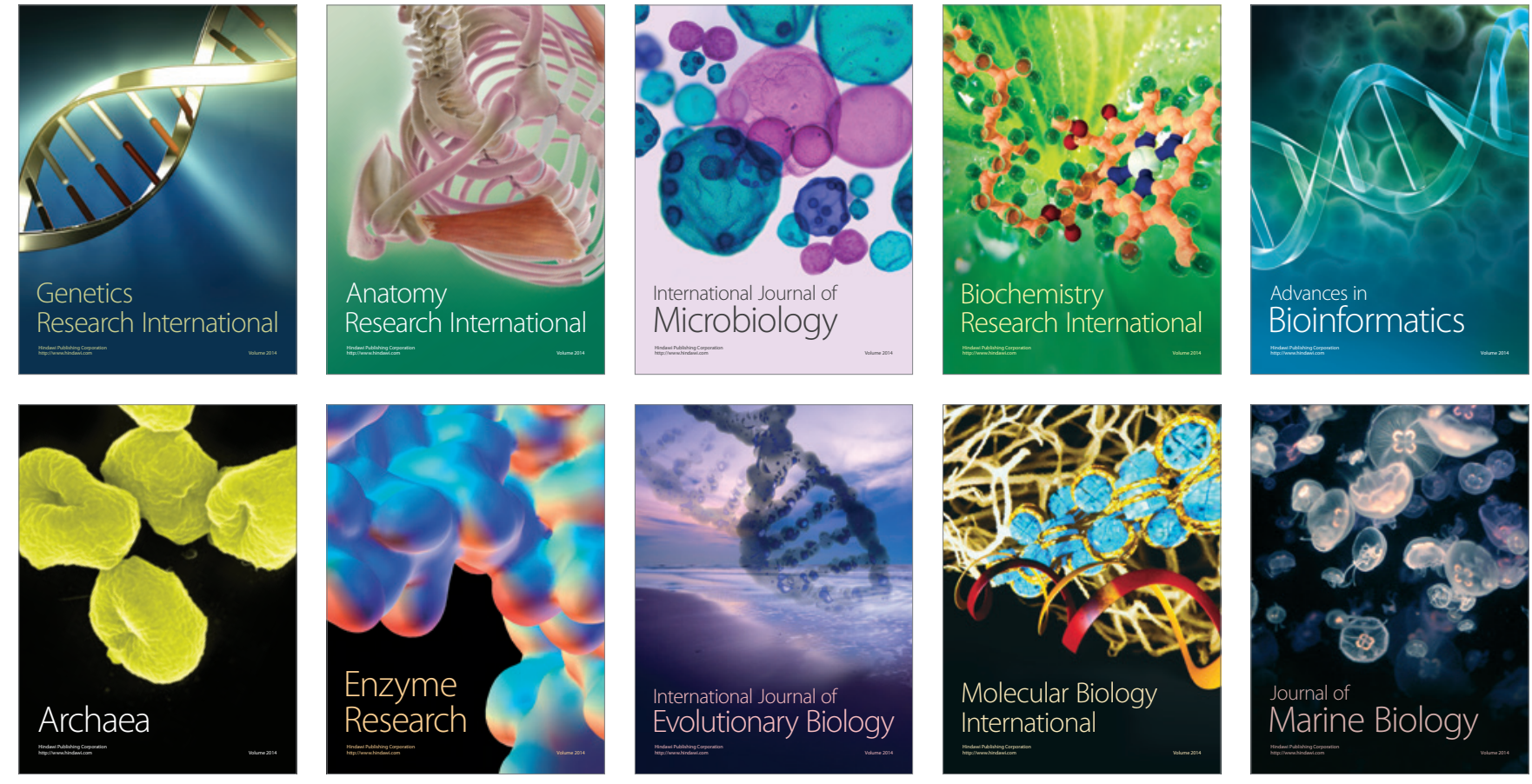